\title{
Application of electron beam water radiolysis for sewage sludge treatment-a review
}

\author{
Malgorzata Siwek $^{1}$ (D) - Thomas Edgecock ${ }^{1}$
}

Received: 20 April 2020 / Accepted: 26 August 2020 / Published online: 6 September 2020

(C) The Author(s) 2020

\begin{abstract}
A review of the applicability of electron beam water radiolysis for sewage sludge treatment is presented. Electron beam treatment has been proven to be a successful approach to the disinfection of both wastewater and sewage sludge. Nevertheless, before 2000, there were concerns about the perceived high capital costs of the accelerator and with public acceptance of the usage of radiation for water treatment purposes. Nowadays, with increased knowledge and technological development, it may be not only possible but also desirable to use electron beam technology for risk-free sewage sludge treatment, disposal and bio-friendly fertiliser production. Despite the developing interest in this method, there has been no attempt to perform a review of the pertinent literature relating to this technology. It appears that understanding of the mechanism and primary parameters of disinfection is key to optimising the process. This paper aims to reliably characterise the sewage sludge electron beam treatment process to elucidate its major issues and make recommendations for further development and research.
\end{abstract}

Keywords Electron beam irradiation $\cdot$ Sewage sludge treatment $\cdot$ Water radiolysis $\cdot G$ value $\cdot$ Free radical scavengers $\cdot$ Electron penetration depth $\cdot$ Wastewater hygienisation

\section{Historical background}

The interest in using accelerated electrons for sewage and sewage sludge treatment has been rising for several decades, and the earliest large-scale studies were started in North America in 1974 (Trump et al. 1984). This led to experiments with a first pilot plant system at the Deer Island Wastewater Treatment Plant in Boston. There was also a research plan undertaken in the Miami-Dade Virginia Key Wastewater Treatment Plant in 1976. The Electron Beam Research Facility (EBRF) was built, and it operated for 1 year (Waite et al. 1985). Extensive industrial-scale research on the application of electron beams for the spent water treatment was conducted in EBRF in 2000 (Kurucz et al. 1995; Nickelsen

Responsible Editor: Vítor Pais Vilar

Malgorzata Siwek

malgorzata.siwek@hud.ac.uk

Thomas Edgecock

t.r.edgecock@hud.ac.uk

1 University of Huddersfield, HD13DH, Queensgate, Huddersfield, West Yorkshire, UK et al. 1994; Tobien et al. 2000; Waite et al. 1985). There was also an investigation of the acceleration technology efficiency in the sewage treatment plant in Kolo, Poland, in cooperation with the Institute of Nuclear Chemistry and Technology in Warsaw (Chmielewski et al. 1995).

The largest commercial venture was the removal of dye from wastewater at the Daegu Dyeing Industrial Complex (DDIC) in Korea. After the construction of a pilot plant, the purification of wastewater from this textile dyeing was applied commercially from 2005 (Han et al. 2012).

Apart from industrial pilot plants, there have also been numerous research studies of electron beam (EB) treatment on the laboratory scale. These fundamental studies have revealed that $\mathrm{EB}$ has a profound influence on bacteria, virus and parasite removal (Borrely et al. 1998; Capodaglio 2017; Chmielewski et al. 1995; Engohang-Ndong et al. 2015; Farooq et al. 1992; Getof 1995; Hossain et al. 2018; Maruthi et al. 2013, Maruthi et al. 2011a; Moraes et al. 2004; Praveen et al. 2013; Pribil et al. 2007; Rawat and Sarma 2013) and the solubility of carbohydrates, proteins and lipids (Changqing and Min 2012; Engohang-Ndong et al. 2015; Lim et al. 2016; Park et al. 2009; Shin and Kang 2003), as well as colour and odour removal (Bae et al. 1999; Engohang-Ndong et al. 2015; Kim et al. 2007; Paul et al. 2011; Tobien et al. 2000). 
Another crucial issue is the electron beam irradiation effect on biochemical oxygen demand (BOD) and chemical oxygen demand (COD), which are used worldwide to measure the number of organic compounds in water (Royal Commission on Sewage Disposal 1915; U.S. Environmental Protection Agency 2011). Many papers claim that BOD and soluble COD increase after penetration by accelerated electrons (Changqing and Min 2012; Han et al. 2012; Kim et al. 2007; Lim et al. 2016; Park et al. 2009; Paul et al. 2011; Shin and Kang 2003), which is thought to be caused by the conversion of non-biodegradable compounds into biodegradable form. Nonetheless, several others say that BOD and COD decrease after EB irradiation (Bae et al. 1999; Farooq et al. 1992; He et al. 2016; Maruthi et al. 2011b; Rawat and Sarma 2013; Zheng et al. 2001), which might be a result of the breakdown of biodegradable components into simple, harmless products such as water, carbon oxides and salts (Cross and Jayaram 1998; Son 2017). Therefore, a closer look at the literature reveals complications in understanding the mechanisms of pollutant removal from the spent water after electron beam application and the need for a review.

\section{The mechanism of the electron beam irradiation}

\section{Sewage sludge direct and indirect radiolysis}

The microbicidal action of ionising radiation (IR) is achieved by its direct (physical) and indirect (chemical) action. When the high energy electrons interact with sewage sludge matter, the ionisation and excitation of molecules can occur (Borrely et al. 1998):

$$
\begin{aligned}
& \text { R. } 1: X Y+e^{-} \rightarrow X Y^{*}+X Y^{+}+e^{-} \\
& \text {R. } 2: X Y^{+}+e^{-} \rightarrow X Y^{*} \\
& \text { R. } 3: X Y^{*} \rightarrow X \bullet+Y \bullet \\
& \text { R. } 4: X Y^{+} \rightarrow X^{+}+Y \bullet
\end{aligned}
$$

Where R. 1-electronic excitation and ionisation, R. 2recombination, R. 3 and R. 4-fragmentation, *-excited molecule, ${ }^{+/}$- cation/anion and $\bullet$-radical.

Once the irradiation is applied, the electrons can interact with the genetic material or some other cellular elements that are essential to the persistence of the organism. This is called a direct effect, and it may ultimately affect the ability of the cell to reproduce and survive. The direct effect of the radiation is thought to play a small part in treating pathogens (Lemée et al. 2017 ) and may only be significant, $>10 \%$ of removal, with organic compounds when the concentration of the contaminant is $\geq 0.1 \mathrm{M}$ (William et al. 2001).

As a result of water radiolysis, several reactive species are formed which can further interact with each other and with the components of the sewage sludge (Cross and Jayaram 1998). This is called an indirect effect. During the water treatment, free radicals and hydrogen peroxide might be generated directly in the biological cell, resulting in its damage or permanent impairment. The biological material destruction efficiency is correlated with the amount of energy absorbed. Actively reducing reactive components $\left(\mathrm{e}^{-}\right.$aq, hydrated electron, and $\mathrm{H} \bullet$, hydrogen radical) and strongly oxidising radical $(\mathrm{OH} \bullet$, hydroxyl radical) are formed all but simultaneously, within $10^{-7} \mathrm{~s}$ of exposure, and in the same order of magnitude concentration (Table 2). This is beneficial to degrade mixed contaminants that could be removed via either oxidation or reduction and that aspect differentiates the EB process from other advanced oxidation technologies (Wang and $\mathrm{Chu}$ 2016). The reactions that take place are given in Table 1, along with their rate constants.

The primary species $\mathrm{H} \bullet, \mathrm{OH} \bullet$ and $\mathrm{e}^{-}$aq, as well as $\mathrm{H}_{2} \mathrm{O}_{2}$, can penetrate the organic molecules, and they are the most reactive.

\section{$G$ value for water irradiation-induced reactive species}

In order to determine the number of radicals produced, the $G$ parameter can be used. $G$ radiation chemical yield (1) is the number of molecules, atoms or free radicals created (or destroyed) per $100 \mathrm{eV}$ of energy deposited in water (Buxton et al. 1988).

$G=\frac{\text { No. of formed molecules }}{100 \mathrm{eV}}$

The main reactive compounds formed after the injection of electrons into the water and their $G$ values (neutral conditions) are as follows (Cross and Jayaram 1998; Engohang-Ndong et al. 2015; Nickelsen et al. 1994; Tobien et al. 2000; Wang and Chu 2016):

$$
\begin{aligned}
& \text { R. 5: } \mathrm{H}_{2} \mathrm{O} \rightarrow[2.7] \mathrm{OH} \bullet+[2.6] \mathrm{e}^{-}{ }_{\text {aq }}+[0.6] \mathrm{H} \bullet+[2.6] \\
& \mathrm{H}_{3} \mathrm{O}^{+}+[0.45] \mathrm{H}_{2}+[0.7] \mathrm{H}_{2} \mathrm{O}_{2}
\end{aligned}
$$

Using the $G$ value in the SI unit of $\mu$ mol of product formed (or destroyed) after the absorption of $1 \mathrm{~J}$ of energy, the approximate concentration of the reactive species can be evaluated (Cooper et al. 2004):

$C_{R C}=D \times G_{\text {valueRC }}$

Where $\mathrm{C}_{\mathrm{RC}}$-reactive compound concentration [ $\mu \mathrm{mol}$ $/ \mathrm{kg}$ ], D — applied dose [ $\mathrm{J} / \mathrm{kg}]$ and $\mathrm{G}_{\text {valueRC }} \mathrm{G}$ value of the reactive compound $[\mu \mathrm{mol} / \mathrm{J}]$. This can be calculated by multiplying the values in R. 5 by 0.1036 .

The approximate content of radicals, hydrogen peroxide and the hydrated electron in pure water at various 
Table 1 Reactions occurring in pure water after the electron beam irradiation and corresponding rate constants according to different authors

\begin{tabular}{|c|c|c|}
\hline Reaction & Rate constant $\left[\mathrm{mol}^{-1} \mathrm{dm}^{3} \mathrm{~s}^{-1}\right]$ & Reference \\
\hline $\mathrm{H} \bullet+\mathrm{O}_{2} \bullet^{-} \rightarrow \mathrm{HO}_{2} \bullet^{-}$ & $2.0 \times 10^{10}$ & William et al. (2001) \\
\hline $\mathrm{H} \bullet+\mathrm{H}_{2} \mathrm{O}_{2} \rightarrow \mathrm{H}_{2} \mathrm{O}+\mathrm{OH} \bullet$ & $9.0 \times 10^{7}$ & Buxton et al. (1988), William et al. (2001) \\
\hline $\mathrm{H} \bullet+\mathrm{O}_{2} \rightarrow \mathrm{HO}_{2} \bullet$ & $2.1 \times 10^{10}$ & William et al. (2001) \\
\hline \multirow[t]{3}{*}{$\mathrm{H} \bullet+\mathrm{H} \bullet \rightarrow \mathrm{H}_{2}$} & $7.8 \times 10^{9}$ & Le Caër (2011) \\
\hline & $5.0 \times 10^{9}$ & William et al. (2001) \\
\hline & $1.3 \times 10^{10}$ & Sun and Chmielewski (2017) \\
\hline $\mathrm{H} \bullet+\mathrm{H}_{2} \mathrm{O} \rightarrow \mathrm{H}_{2}+\mathrm{OH} \bullet$ & $1 \times 10^{1}$ & Buxton et al. (1988), William et al. (2001) \\
\hline $\mathrm{H} \bullet+\mathrm{HO}_{2} \bullet \rightarrow \mathrm{H}_{2} \mathrm{O}_{2}$ & $1.0 \times 10^{10}$ & William et al. (2001) \\
\hline $\mathrm{H} \bullet+\mathrm{OH}^{-} \rightarrow \mathrm{e}^{-}+\mathrm{H}_{2} \mathrm{O}$ & $2.2 \times 10^{7}$ & William et al. (2001) \\
\hline \multirow[t]{2}{*}{$\mathrm{e}_{\mathrm{aq}}^{-}+\mathrm{H}_{2} \mathrm{O}_{2} \rightarrow \mathrm{OH} \bullet+\mathrm{OH}^{-}$} & $1.2 \times 10^{10}$ & Kurucz et al. (1991), William et al. (2001) \\
\hline & $1.1 \times 10^{10}$ & Buxton et al. (1988) \\
\hline $\mathrm{e}_{\mathrm{aq}}^{-}+\mathrm{OH} \bullet \rightarrow \mathrm{OH}^{-}$ & $3.0 \times 10^{10}$ & Buxton et al. (1988), Khan et al. (2015), Le Caër (2011), William et al. (2001) \\
\hline $\mathrm{e}^{-}{ }_{\mathrm{aq}}+\mathrm{H}^{+} \rightarrow \mathrm{H} \bullet$ & $2.3 \times 10^{10}$ & Buxton et al. (1988), Tobien et al. (2000), Wang and Chu (2016) \\
\hline $\mathrm{e}^{-}{ }_{\mathrm{aq}}+\mathrm{H}_{3} \mathrm{O}^{+} \rightarrow \mathrm{H} \bullet+\mathrm{H}_{2} \mathrm{O}$ & $2.3 \times 10^{10}$ & Le Caër (2011) \\
\hline $\mathrm{e}_{\mathrm{aq}}^{-}+\mathrm{e}_{\mathrm{aq}}+2 \mathrm{H}_{2} \mathrm{O} \rightarrow \mathrm{H}_{2}+2 \mathrm{OH}^{-}$ & $5.5 \times 10^{9}$ & Buxton et al. (1988), Le Caër (2011) \\
\hline $\mathrm{e}^{-} \mathrm{aq}+\mathrm{H} \bullet+\mathrm{H}_{2} \mathrm{O} \rightarrow \mathrm{H}_{2}+\mathrm{OH}^{-}$ & $2.5 \times 10^{10}$ & Le Caër (2011) \\
\hline \multirow[t]{2}{*}{$\mathrm{e}^{-}{ }_{\text {aq }}+\mathrm{H}_{2} \mathrm{O} \rightarrow \mathrm{H} \bullet+\mathrm{OH}^{-}$} & $1.9 \times 10^{1}$ & Buxton et al. (1988) \\
\hline & $8.9 \times 10^{2}$ & William et al. (2001) \\
\hline $\mathrm{e}^{-}{ }_{\mathrm{aq}}+\mathrm{H} \bullet \rightarrow \mathrm{H}_{2}+\mathrm{OH}^{-}$ & $2.5 \times 10^{10}$ & Buxton et al. (1988) \\
\hline $\mathrm{e}_{\mathrm{aq}}^{-}+\mathrm{O}^{-} \rightarrow 2 \mathrm{OH}^{-}$ & $2.2 \times 10^{10}$ & Buxton et al. (1988), William et al. (2001) \\
\hline $\mathrm{e}_{\mathrm{aq}}^{-}+\mathrm{HO}_{2}^{-} \rightarrow 2 \mathrm{OH}^{-}+\mathrm{OH} \bullet$ & $3.5 \times 10^{9}$ & William et al. (2001) \\
\hline $\mathrm{e}^{-}{ }_{\mathrm{aq}}+\mathrm{O}_{2} \rightarrow \mathrm{O}_{2} \bullet^{-}$ & $1.9 \times 10^{10}$ & Buxton et al. (1988), Getof (1995), William et al. (2001) \\
\hline $\mathrm{e}_{\mathrm{aq}}^{-}+\mathrm{O}_{2}^{-} \cdot \rightarrow \mathrm{O}_{2}^{2-}$ & $1.3 \times 10^{10}$ & Buxton et al. (1988) \\
\hline $\mathrm{OH} \bullet+\mathrm{H}_{2} \rightarrow \mathrm{H} \bullet+\mathrm{H}_{2} \mathrm{O}$ & $4.2 \times 10^{7}$ & Buxton et al. (1988) \\
\hline $\mathrm{OH} \bullet+\mathrm{OH} \bullet \rightarrow \mathrm{H}_{2} \mathrm{O}_{2}$ & $5.5 \times 10^{9}$ & Khan et al. (2015), Le Caër (2011) \\
\hline $\mathrm{OH} \bullet+\mathrm{HO}_{2} \bullet \rightarrow \mathrm{H}_{2} \mathrm{O}+\mathrm{O}_{2}$ & $6.0 \times 10^{9}$ & Buxton et al. (1988) \\
\hline \multirow[t]{2}{*}{$\mathrm{OH} \bullet+\mathrm{H} \bullet \rightarrow \mathrm{H}_{2} \mathrm{O}$} & $7.0 \times 10^{9}$ & Buxton et al. (1988), Khan et al. (2015), Wang and Chu (2016) \\
\hline & $2.0 \times 10^{10}$ & Le Caër (2011) \\
\hline \multirow[t]{2}{*}{$\mathrm{OH} \bullet+\mathrm{OH}^{-} \rightarrow \mathrm{O}^{-}+\mathrm{H}_{2} \mathrm{O}$} & $1.2 \times 10^{10}$ & Wang and Chu (2016) \\
\hline & $1.3 \times 10^{10}$ & Buxton et al. (1988), William et al. (2001) \\
\hline $\mathrm{OH} \bullet+\mathrm{HO}_{2}^{-} \rightarrow \mathrm{H}_{2} \mathrm{O}+\mathrm{O}_{2} \bullet^{-}$ & $7.5 \times 10^{9}$ & William et al. (2001) \\
\hline \multirow[t]{2}{*}{$\mathrm{OH} \bullet+\mathrm{O}_{2} \bullet^{-} \rightarrow \mathrm{OH}^{-}+\mathrm{O}_{2}$} & $8 \times 10^{9}$ & Buxton et al. (1988) \\
\hline & $1.1 \times 10^{10}$ & William et al. (2001) \\
\hline $\mathrm{O} \bullet+\mathrm{H}_{2} \mathrm{O}_{2} \rightarrow \mathrm{O}_{2} \bullet^{-}+\mathrm{H}_{2} \mathrm{O}$ & $2.7 \times 10^{7}$ & William et al. (2001) \\
\hline $\mathrm{O}^{-}+\mathrm{H}_{2} \mathrm{O} \rightarrow \mathrm{OH}^{-}+\mathrm{OH}^{\bullet}$ & $1.8 \times 10^{6}$ & Buxton et al. (1988) \\
\hline $\mathrm{O}^{-}+\mathrm{H}_{2} \rightarrow \mathrm{H}^{\bullet}+\mathrm{OH}^{-}$ & $8.0 \times 10^{7}$ & Buxton et al. (1988) \\
\hline $\mathrm{O}^{-}+\mathrm{HO}_{2}^{-} \rightarrow \mathrm{O}_{2}^{\cdot} \cdot+\mathrm{OH}^{-}$ & $4.0 \times 10^{8}$ & Buxton et al. (1988) \\
\hline $\mathrm{O}^{-}+\mathrm{O}_{2} \cdot^{-} \rightarrow 2 \mathrm{OH}^{-}+\mathrm{O}_{2}$ & $6.0 \times 10^{8}$ & William et al. (2001) \\
\hline $\mathrm{H}_{3} \mathrm{O}^{+}+\mathrm{OH}^{-} \rightarrow 2 \mathrm{H}_{2} \mathrm{O}$ & $1.4 \times 10^{11}$ & Le Caër (2011), Sun and Chmielewski (2017) \\
\hline $\mathrm{HO}_{2}^{\bullet}+\mathrm{O}_{2} \bullet^{-} \rightarrow \mathrm{H}_{2} \mathrm{O}_{2}+\mathrm{O}_{2}+\mathrm{OH}^{-}$ & $9.7 \times 10^{7}$ & William et al. (2001) \\
\hline $\mathrm{HO}_{2} \bullet+\mathrm{HO}_{2} \bullet \rightarrow \mathrm{H}_{2} \mathrm{O}_{2}+\mathrm{O}_{2}$ & $8.3 \times 10^{5}$ & William et al. (2001) \\
\hline
\end{tabular}

doses using high energy electron acceleration is presented in Table 2 (Cooper et al. 2004).
As the dose increases, such a simple estimation may no longer be strictly accurate, and the concentration might be 
Table 2 The estimated concentration of reactive components at various doses using the electron beam (based on Cooper et al. 2004)

\begin{tabular}{lllll}
\hline Dose $[\mathrm{kGy}]$ & \multicolumn{4}{l}{ Concentration $[\mathrm{mM}]$} \\
\cline { 2 - 5 } & $\mathrm{e}^{-}{ }_{\text {aq }}$ & $\mathrm{H} \bullet$ & $\mathrm{OH}$ & $\mathrm{H}_{2} \mathrm{O}_{2}$ \\
\hline 1 & 0.27 & 0.06 & 0.28 & 0.07 \\
5 & 1.4 & 0.3 & 1.4 & 0.4 \\
10 & 2.7 & 0.6 & 2.8 & 0.7 \\
15 & 4.1 & 0.9 & 4.2 & 1 \\
\hline
\end{tabular}

over-estimated (the contribution of direct effect increases). However, in the highly contaminated environment of sewage sludge, where the reactive species action is being rapidly inhibited, this assumption provides an order-of-magnitude estimation of the compounds available for reaction with the organic or inorganic contamination (William et al. 2001). An approximate removal percentage can be calculated for each species (3) (Nickelsen et al. 1994). As an example, the estimated $\mathrm{e}^{-}$aq, $\mathrm{H} \bullet$ and $\mathrm{OH} \bullet$ contributions in toluene and benzene removal are presented in Table 3.

$C_{x}=\frac{k_{x} \times G_{x} \times 100 \%}{k_{x} \times G_{x}+k_{y} \times G_{y}+k_{z} \times G_{z}}$

Where $k_{x, y, z}$ are rate constants $\left[\mathrm{mol}^{-1} \mathrm{dm}^{3} \mathrm{~s}^{-1}\right]$ of reactions between the contaminant and the $x, y, z$ reactive species; $G_{x, y, z}$ are the $G$ values of $x, y, z$ radical formation; and $C_{x}$ is the $x$ radical contribution in contaminant removal.

Using the $G$ value allows the identification of the most substantial radicals for specific contaminants and should be one of the first steps when designing wastewater or sewage sludge electron beam installation, where specific contaminants are present.

\section{Free radical scavengers}

In order to extend the laboratory data to natural conditions, the composition of sewage sludge should be considered. Nonetheless, while thousands of experiments have been carried out on the radiolytic destruction of various groups of

Table 3 The approximate responsibility of each reactive species for toluene and benzene removal (based on Nickelsen et al. 1994)

\begin{tabular}{llll}
\hline Component & \multicolumn{3}{l}{ Contribution in disinfection effect [\%] } \\
\cline { 2 - 4 } & $\mathrm{e}^{-}$ & $\mathrm{H} \bullet$ & $\mathrm{OH} \bullet$ \\
\hline Toluene & 0.1 & 2.5 & 97.4 \\
Benzene & 0.4 & 16.1 & 83.5 \\
\hline
\end{tabular}

environmental contaminants, these were tested mostly on single-component, synthetic solutions. In real conditions (sewage sludge, wastewater/natural water with a complex matrix), many constituents naturally present in solution were observed to scavenge the production of the reactive chemical species during electron beam irradiation (e.g. $\mathrm{O}_{2}, \mathrm{HCO}_{3}^{-;}, \mathrm{CO}_{3}{ }^{2}$ ${ }^{-}, \mathrm{Cl}^{-}, \mathrm{NO}_{2}^{-}, \mathrm{NO}_{3}^{-}$) decreasing or increasing the overall process efficiency (Capodaglio 2017; Wang and Chu 2016; William et al. 2001).

Scavengers are defined as chemical compounds (or ions and radicals), which react with reactive species produced by radiolysis. Such additional, both organic and inorganic, chemicals can compete with the target pollutant. Some wellknown natural water scavengers are oxygen, bicarbonate/ carbonate ions, and nitrate ions as well as dissolved organic carbon (DOC) (Wang and Chu 2016; William et al. 2001) or heavy metal (HM) ions (Duarte et al. 2004; William et al. 2001). Oxygen is reduced by rapid reaction with both $\mathrm{e}^{-}$aq and $\mathrm{H} \bullet$, while nitrate ions act as an $\mathrm{e}^{-}$aq scavenger, and during radiolysis, they are reduced to nitrite ions. The $\mathrm{NO}_{2}{ }^{-}$can further react with the $\mathrm{OH} \bullet$ and this promotes the addition of $\mathrm{NO}_{2}$ to aromatic solutes if present (Wang and Chu 2016; William et al. 2001). The carbonate ion is an ascertained hydroxyl radical scavenger, and both carbonate and bicarbonate ions are used for the alkalinity estimation of natural systems. However, the scavenging effect of alkalinity on $\mathrm{OH} \bullet$ radical is strictly dependent upon the solution $\mathrm{pH}$ (William et al. 2001). This phenomenon is described in detail in the "pH influence" section. The metal concentration is also a parameter of high importance. It has been reported that some of the main products of water irradiation are scavenged by the metal ions (Duarte et al. 2004). As described in "Heavy metal influence and removal" section, this makes it possible to use the electron beam for HM removal.

Rate constants of reactions between chemical species typically found in natural water (nitrate, nitrite, carbonate, bicarbonate ions and oxygen) and reactive components created during the water radiolysis are listed in Table 4.

Scavengers are mostly known as harmful components, which can react with radicals and make them no longer available for the contamination removal. While the negative aspect of scavenger occurrence is indisputable, the benefit from its presence might not be as evident. After the identification of a potential reactive species, which is responsible for removing the pollution of interest, it is necessary to study its main reactions with other radicals. It may be favourable to remove expendable reactive species using scavengers, for overall efficiency improvement. For instance, if the destruction of $\mathrm{CCl}_{4}$, which reacts with hydrated electron is an objective, one way to raise the removal efficiency (the effective concentration of $\mathrm{e}^{-}$aq $)$is to dispose of $\mathrm{OH} \bullet$, because the hydroxyl radical reacts with $\mathrm{e}^{-}$aq (Table 1), but does not react with carbon tetrachloride (International Atomic Energy Agency 2005; William 
Table 4 Examples of chemical reactions and rate constants for various scavengers

\begin{tabular}{|c|c|c|c|}
\hline Scavenger & Reaction & Rate constant $\left[\mathrm{mol}^{-1} \mathrm{dm}^{3} \mathrm{~s}^{-1}\right]$ & Reference \\
\hline \multirow[t]{2}{*}{ Carbonate ion } & $\mathrm{CO}_{3}{ }^{2-}+\mathrm{OH} \bullet \rightarrow \mathrm{CO}_{3} \bullet^{-}+\mathrm{OH}$ & $3.9 \times 10^{8}$ & $\begin{array}{l}\text { (Buxton et al. (1988), Nickelsen et al. (1994), } \\
\text { Wang and Chu (2016) }\end{array}$ \\
\hline & $\mathrm{CO}_{3}^{2-}+\mathrm{e}_{\mathrm{aq}}^{-} \rightarrow$ PDTS & $3.5 \times 10^{5}$ & William et al. (2001) \\
\hline \multirow[t]{3}{*}{ Bicarbonate ion } & $\mathrm{HCO}_{3}^{-}+\mathrm{OH} \bullet \rightarrow \mathrm{CO}_{3}{ }^{-}+\mathrm{H}_{2} \mathrm{O}$ & $8.5 \times 10^{6}$ & $\begin{array}{l}\text { Nasseri et al. (2017), Nickelsen et al. (1994), } \\
\text { Wang and Chu (2016) }\end{array}$ \\
\hline & $\mathrm{HCO}_{3}{ }^{-}+\mathrm{H} \bullet \rightarrow$ PDTS & $4.4 \times 10^{4}$ & William et al. (2001) \\
\hline & $\mathrm{HCO}_{3}^{-}+\mathrm{e}_{\mathrm{aq}}^{-} \rightarrow$ PDTS & $1.0 \times 10^{6}$ & William et al. (2001) \\
\hline \multirow[t]{2}{*}{ Nitrite ion } & $\mathrm{NO}_{2}^{-}+\mathrm{OH} \bullet \rightarrow \mathrm{NO}_{2} \bullet+\mathrm{OH}^{-}$ & $8.0 \times 10^{9}$ & Wang and Chu (2016) \\
\hline & $\mathrm{NO}_{2}^{-}+\mathrm{e}^{-}$aq $\rightarrow \mathrm{NO}_{2} \bullet^{-}$ & $3.5 \times 10^{9}$ & Wang and Chu (2016) \\
\hline \multirow[t]{2}{*}{ Nitrate ion } & $\mathrm{NO}_{3}^{-}+\mathrm{e}^{-}{ }_{\mathrm{aq}}^{-} \rightarrow \mathrm{NO}_{3} \bullet^{2-}$ & $9.7 \times 10^{9}$ & $\begin{array}{l}\text { Buxton et al. (1988), Wang and Chu (2016), } \\
\text { William et al. (2001) }\end{array}$ \\
\hline & $\mathrm{NO}_{3}^{-}+\mathrm{H} \cdot \rightarrow$ PDTS & $1.4 \times 10^{6}$ & William et al. (2001) \\
\hline \multirow[t]{3}{*}{ DOC } & $\mathrm{DOC}+\mathrm{e}_{\mathrm{aq}}^{-} \rightarrow$ PDTS & $1.0 \times 10^{7}$ & William et al. (2001) \\
\hline & $\mathrm{DOC}+\mathrm{OH} \bullet \rightarrow \mathrm{PDTS}$ & $1.0 \times 10^{7}$ & William et al. (2001) \\
\hline & $\mathrm{DOC}+\mathrm{H} \bullet \rightarrow \mathrm{PDTS}$ & $1.0 \times 10^{8}$ & William et al. (2001) \\
\hline \multirow[t]{3}{*}{ Methanol } & $\begin{array}{l}\mathrm{CH}_{3} \mathrm{OH}+\mathrm{OH} \cdot \rightarrow \mathrm{H}_{2} \mathrm{O}+ \\
\quad \mathrm{CH}_{2} \mathrm{OH} \cdot(93 \%)+\mathrm{CH}_{3} \mathrm{O} \cdot(7 \%)\end{array}$ & $9.7 \times 10^{8}$ & $\begin{array}{l}\text { Buxton et al. (1988), Nickelsen et al. (1994), } \\
\text { Wang and Chu (2016) }\end{array}$ \\
\hline & $\mathrm{CH}_{3} \mathrm{OH}+\mathrm{e}_{\mathrm{aq}}^{-} \rightarrow \mathrm{H} \bullet+\mathrm{CH}_{3} \mathrm{O}^{-}$ & $<1.0 \times 10^{4}$ & Wang and Chu (2016) \\
\hline & $\mathrm{CH}_{3} \mathrm{OH}+\mathrm{H} \bullet \rightarrow \mathrm{H}_{2}+\mathrm{CH}_{2} \mathrm{OH} \bullet$ & $2.6 \times 10^{6}$ & Nickelsen et al. (1994) \\
\hline \multirow[t]{5}{*}{$t$-BuOH } & $\mathrm{C}_{4} \mathrm{H}_{9} \mathrm{OH}+\mathrm{OH} \bullet \rightarrow \mathrm{H}_{2} \mathrm{O}+\mathrm{C}_{4} \mathrm{H}_{8} \mathrm{OH} \bullet$ & $6.0 \times 10^{8}$ & $\begin{array}{l}\text { Buxton et al. (1988), Tobien et al. (2000), } \\
\text { Wang and Chu (2016), Wojnarovits et al. (2005) }\end{array}$ \\
\hline & & $3.8-7.6 \times 10^{8}$ & Nasseri et al. (2017) \\
\hline & $\mathrm{C}_{4} \mathrm{H}_{9} \mathrm{OH}+\mathrm{e}^{-}{ }_{\text {aq }} \rightarrow \mathrm{H} \bullet+\mathrm{C}_{4} \mathrm{H}_{9} \mathrm{O}^{-}$ & $4.0 \times 10^{5}$ & Wang and Chu (2016) \\
\hline & $\mathrm{C}_{4} \mathrm{H}_{9} \mathrm{OH}+\mathrm{H} \bullet \rightarrow \mathrm{H}_{2}+\mathrm{C}_{4} \mathrm{H}_{8} \mathrm{OH} \bullet$ & $8.0 \times 10^{4}$ & Zona et al. (2008) \\
\hline & & $10^{5}$ & Buxton et al. (1988) \\
\hline \multirow[t]{2}{*}{ Thiourea } & $\mathrm{H}_{2} \mathrm{NCSNH}_{2}+\mathrm{OH} \bullet \rightarrow$ PDTS & $3.9 \times 10^{9}$ & Wang and Chu (2016) \\
\hline & $\mathrm{H}_{2} \mathrm{NCSNH}_{2}+\mathrm{e}_{\text {aq }}^{-} \rightarrow$ PDTS & $2.9 \times 10^{9}$ & Wang and Chu (2016) \\
\hline \multirow[t]{2}{*}{ Isopropanol } & $\mathrm{C}_{3} \mathrm{H}_{7} \mathrm{OH}+\mathrm{OH} \bullet \rightarrow \mathrm{H}_{2} \mathrm{O}+\mathrm{C}_{3} \mathrm{H}_{6} \mathrm{OH} \bullet$ & $1.9 \times 10^{9}$ & Wang and Chu (2016) \\
\hline & $\mathrm{C}_{3} \mathrm{H}_{7} \mathrm{OH}+\mathrm{H} \bullet \rightarrow \mathrm{H}_{2}+\mathrm{C}_{3} \mathrm{H}_{6} \mathrm{OH} \bullet$ & $7.4 \times 10^{7}$ & Wang and Chu (2016) \\
\hline \multirow[t]{2}{*}{ Nitrous oxide } & $\mathrm{N}_{2} \mathrm{O}+\mathrm{H} \bullet \rightarrow \mathrm{OH} \bullet+\mathrm{N}_{2}$ & $2.1 \times 10^{9}$ & Wang and Chu (2016) \\
\hline & $\mathrm{N}_{2} \mathrm{O}+\mathrm{e}^{-}{ }_{\text {aq }}+\mathrm{H}_{2} \mathrm{O} \rightarrow \mathrm{OH} \bullet+\mathrm{N}_{2}+\mathrm{OH}^{-}$ & $9.1 \times 10^{9}$ & $\begin{array}{l}\text { Buxton et al. (1988), Getof (1995), Tobien et al. (2000), } \\
\text { Wang and Chu (2016), Wojnarovits et al. (2005) }\end{array}$ \\
\hline \multirow[t]{2}{*}{ Chloride ion } & $\mathrm{Cl}^{-}+\mathrm{OH} \bullet \rightarrow \mathrm{ClOH}^{-}$ & $4.3 \times 10^{9}$ & Wang and Chu (2016) \\
\hline & & $6.1(+/-0.8) \times 10^{9}$ & Nasseri et al. (2017) \\
\hline Sulfate ion & $\mathrm{SO}_{4}{ }^{2-}+\mathrm{e}_{\mathrm{aq}}^{-} \rightarrow \mathrm{SO}_{4}{ }^{3-}$ & $1.0 \times 10^{6}$ & Wang and Chu (2016) \\
\hline \multirow[t]{2}{*}{ Bromide ion } & $\mathrm{Br}^{-}+\mathrm{H} \bullet \rightarrow$ PDTS & $2.8 \times 10^{7}$ & William et al. (2001) \\
\hline & $\mathrm{Br}^{-}+\mathrm{OH} \bullet \rightarrow$ PDTS & $1.1 \times 10^{10}$ & William et al. (2001) \\
\hline \multirow[t]{2}{*}{ Chloramine } & $\mathrm{NH}_{2} \mathrm{Cl}+\mathrm{e}_{\text {aq }}^{-} \rightarrow$ PDTS & $1.0 \times 10^{8}$ & William et al. (2001) \\
\hline & $\mathrm{NH}_{2} \mathrm{Cl}+\mathrm{OH} \bullet \rightarrow$ PDTS & $1.0 \times 10^{8}$ & William et al. (2001) \\
\hline Ferrocyanide ion & $\mathrm{Fe}(\mathrm{CN})_{6}{ }^{4-}+\mathrm{OH} \bullet \rightarrow \mathrm{Fe}(\mathrm{CN})_{6}^{3-}+\mathrm{OH}^{-}$ & $1.1 \times 10^{10}$ & Buxton et al. (1988) \\
\hline \multirow[t]{2}{*}{ Chloroacetic acid } & $\mathrm{ClC}_{2} \mathrm{H}_{3} \mathrm{O}_{2}+\mathrm{H} \bullet \rightarrow \mathrm{C}_{2} \mathrm{H}_{2} \mathrm{ClO}_{2}+\mathrm{H}_{2}$ & $1.8 \times 10^{5}$ & Stadlbauer et al. (1997) \\
\hline & $\mathrm{ClC}_{2} \mathrm{H}_{3} \mathrm{O}_{2}+\mathrm{e}_{\mathrm{aq}}^{-} \rightarrow \mathrm{C}_{2} \mathrm{H}_{3} \mathrm{O}_{2} \bullet+\mathrm{Cl}^{-}$ & $1.9 \times 10^{9}$ & Buxton et al. (1988) \\
\hline \multirow[t]{2}{*}{ Oxygen } & $\mathrm{O}_{2}+\mathrm{e}_{\mathrm{aq}}^{-} \rightarrow \mathrm{O}_{2} \bullet^{-}$ & $1.9 \times 10^{10}$ & Buxton et al. (1988), William et al. (2001) \\
\hline & $\mathrm{O}_{2}+\mathrm{H} \bullet \rightarrow \mathrm{HO}_{2} \bullet$ & $2.1 \times 10^{10}$ & William et al. (2001) \\
\hline
\end{tabular}

PDTS products 
et al. 2001). Such a procedure would leave a hydrated electron to react with the contaminant, and the removal efficiency is increased. The same course of action may be repeated for any radical-pollutant pair, and after a deep investigation of sewage sludge components, the presence of scavengers may be used to improve efficacy.

Nonetheless, the sewage sludge composition is often the main problem when considering the strengthening of the positive scavengers' influence or their detrimental effect reduction. In the past two decades, the numerous, emerging contaminants have been detected in wastewaters and their sludge, such as persistent organic pollutants (POPs) (pesticides, industrial chemicals, chemical by-products like hexachlorobenzene, polychlorinated dibenzofurans) (Changqing and Min 2012), anti-inflammatory drugs and antibiotics (Wang and Chu 2016) as well as antibiotic-resistant genes (Liao Yinguang Chen 2018) and microplastics (Carr et al. 2016; Eckert et al. 2018; Gies et al. 2018; Lasee et al. 2017; Murphy et al. 2016; Prata 2018; Talvitie et al. 2017; Ziajahromi et al. 2017). The electron beam is proven to be efficient for the reduction of 4-chlorophenol (International Atomic Energy Agency 2005), chloroform, dichloroethane, methyl isobutyl ketone, xylene and phenol (Duarte et al. 2004, 2002), pesticides, polycyclic aromatic hydrocarbons (PAHs) and polychlorinated biphenyls (PCBs) (Changqing and Min 2012), various azo dyes (Han et al. 2012, 2002; He et al. 2016; Kim et al. 2006; Paul et al. 2011; Takács et al. 2007; Wojnárovits and Takács 2008), benzene (Duarte et al. 2004; Gholami et al. 2014; Nickelsen et al. 1994), toluene (Duarte et al. 2004, 2002; Nickelsen et al. 1994) and trichloroethylene (Cross and Jayaram 1998) as well as personal and pharmaceutical care products (PPCPs) and many others. However, when the contaminants' content is very high (i.e. industrial discharges), the initial radical attack results in the by-products' formation, known as transformation products. These by-products may consequently react with the free radicals and play a role of the scavenger by competition with the pollutant of interest. Therefore, as the treatment proceeds (or dose increases), the removal efficiency may decrease. For low concentrated solutions, the process more likely destroys the reaction by-products along with the initial solute; hence, the removal efficiency increases with time and with higher doses (William et al. 2001). Nevertheless, since the likelihood of by-product occurrence is relatively high due to the complexity of the sewage sludge matrix, the content of the mentioned, dangerous contaminants should always be considered. Examples of chemical reactions between reactive species and various scavengers as well as their rate constants (in pure water) are listed in Table 4. However, the more complicated the wastewater and sewage sludge matrix is, the more elaborate the assessment of scavenging influence, because it may be affected by the presence of different chemicals.

\section{$\mathrm{pH}$ influence}

The electron beam-induced decomposition of organic and inorganic pollutants is a result of their reaction with the water treatment products, such as $\mathrm{e}^{-}{ }_{\text {aq }}, \mathrm{H} \bullet$ and $\mathrm{OH} \bullet$. Since radicals and hydrated electron can also react with the products of water hydrolysis $\left(\mathrm{H}_{3} \mathrm{O}^{+}, \mathrm{OH}^{-}\right)$, the $\mathrm{pH}$ value can significantly change their initial yields ( $G$ values), as shown below (Fig. 1).

At acid conditions, $\mathrm{e}_{\text {eq }}^{-}$might react with hydrogen ion to produce a hydrogen radical (Table 1), which most likely leads to the radical recombination reaction (Wang and Chu 2016). Therefore, the amount of $\mathrm{OH} \bullet$ radicals is reduced. At alkaline $\mathrm{pH}$, the highly oxidising $\mathrm{OH} \bullet$ transforms readily to less reactive $\mathrm{O}^{-}$radical (Buxton et al. 1988; Wang and Chu 2016; William et al. 2001). It is claimed (William et al. 2001) that the scavenging effect on hydroxyl radicals in untreated water $(\mathrm{pH} 9)$ is 2.5 times higher than in secondary wastewater $(\mathrm{pH}$ 7). It is well documented that pollutant destruction efficiency is profoundly lower in alkaline conditions. Likewise, in many cases, the degradation of contaminant decreases in strong acid conditions (generally $\mathrm{pH}<2.0$ ), but it is favoured at weak acid to neutral conditions (Bae et al. 1999; Getof 1995; Nickelsen et al. 1994; Park et al. 2009; Paul et al. 2011; Shin and Kang 2003; Tobien et al. 2000; Wang and Chu 2016; William et al. 2001; Zona et al. 2008).

It can be seen (Fig. 1) that the range of interest for highly productive treatment $\left(\mathrm{e}^{-}{ }_{\text {aq }}, \mathrm{OH} \bullet\right)$ is relatively wide. The number of priority reactive species is significant at $\mathrm{pH}$ between 4 and 10. Regarding the complex composition of sewage sludge, the presence of both oxidising $(\mathrm{OH} \bullet)$ and reducing $\left(\mathrm{e}^{-}\right.$aq $)$elements is strongly desirable. A closer look at the literature reveals that the general assessment of the most beneficial environment $(\mathrm{pH})$ for electron beam sewage sludge irradiation has not been done so far. Nevertheless, the chemistry

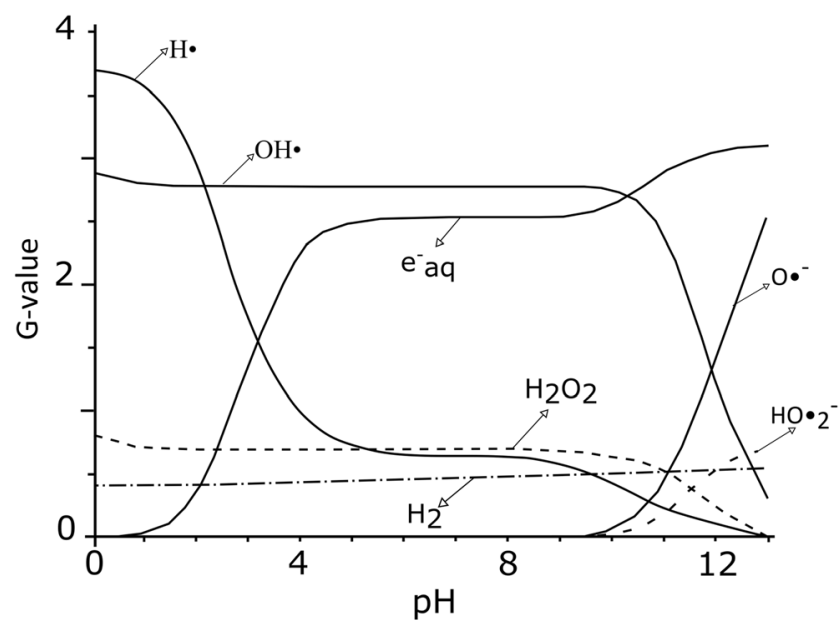

Fig. 1 The $\mathrm{pH}$ value impact on the main water radiolysis products. $G$ values of the primary reactive species formed after the electron beam water irradiation is shown as a function of $p H$ (based on Getof 1995; Wang and Chu 2016; Zona et al. 2008) 
of such waste should always be considered first. The constitution of sludge or wastewater of different origins may require the use of different radicals. Thus, controlling of solution $\mathrm{pH}$ is a parameter, which may relatively easily increase the electron beam treatment efficiency.

\section{Heavy metal influence and removal}

Since the heavy metals can react with the water radiolysis products, they are known as scavengers. Simultaneously, it is possible to use the EB installation to remove HMs from liquid waste. The method is based on the radiation chemical reduction of the metal ions to their respective metals or to lower oxidation state ions which can then be removed by filtration (Pikaev et al. 1997; Schmelling et al. 1998). The reduction upon electron beam treatment can be a result of reactions of the ions with hydrated electrons $\mathrm{e}^{-}$aq and $\mathrm{H} \cdot$ atoms, formed from water radiolysis. There are two requirements for heavy metal removal to take place: the absence of oxygen in the water (in the case of $\mathrm{Cd}^{\mathrm{II}}$ and $\mathrm{Pb}^{\mathrm{II}}$ ) and scavenging of $\mathrm{OH}$ - radicals (e.g. by formate presence), which can oxidise the reduced metal ions (Pikaev et al. 1997). Since the hydroxyl radicals are the main components responsible for chemical and biological contaminant destruction, it is not possible to remove the HMs simultaneously with the other contaminants.

\section{Influence of the presence of pathogens}

There have been multiple pathogens detected in sludge samples, and their presence is mostly dependent on sludge origin (whether industrial, pharmaceutical or municipal) and geographical location (Maruthi et al. 2013; Tell et al. 2019). The list of the most common pathogens that have been found in the raw sludge can be seen in Table 5.

Amongst all of the pathogen groups, there are several species of particular importance due to the severity of the disease they cause or their infectiousness and prevalence. The summary of the most significant representatives is shown in Table 6.

Both the indirect and direct effects (see "Sewage sludge direct and indirect radiolysis" section) on pathogens caused by the EB are thought to result in the damage of DNA and RNA molecules. Nevertheless, the sensitivity of microorganisms to the accelerated electron beam varies significantly from one species to another. Decimal reduction dose $\left(D_{10}\right)$ is defined as the dose required for killing $90 \%$ of the microorganism population or the dose required for a one-log inactivation and is given by (van Gerwen et al. 2016)

$\log \frac{b}{b_{0}}=-\frac{1}{D_{10}} D$

Table 5 List of pathogens that can be found in raw sludge (adapted from Skowron et al. 2018)

\begin{tabular}{|c|c|c|c|}
\hline Pathogen type & Detected group & Pathogen type & Detected group \\
\hline Bacteria & $\begin{array}{l}\text { Coliforms } \\
\text { Faecal coliforms } \\
\text { Faecal streptococci } \\
\text { Enterococci } \\
\text { Clostridium perfringens } \\
\text { Staphylococcus (coagulase positive) } \\
\text { Pseudomonas aeruginosa } \\
\text { Acid-fast bacteria } \\
\text { Coliphages } \\
\text { Bacteroides }\end{array}$ & Viruses & $\begin{array}{l}\text { Adenovirus, Alfavirus (African swine fever) } \\
\text { Enterovirus } \\
\text { Herpesvirus } \\
\text { Parvovirus } \\
\text { Picornavirus (foot and mouth disease) } \\
\text { Reoviridae } \\
\text { Rinovirus }\end{array}$ \\
\hline Fungi & $\begin{array}{l}\text { Candida } \text { spp. } \\
\text { Cryptococcus } \text { spp. } \\
\text { Geotrichum } \text { spp. } \\
\text { Rhodotorula } \text { spp. } \\
\text { Trichosporon spp. } \\
\text { Torulopsis spp. } \\
\text { Mucor } \text { spp. } \\
\text { Penicillium spp. } \\
\text { Aspergillus spp. } \\
\text { Botryotrichum } \text { spp. }\end{array}$ & Parasites & $\begin{array}{l}\text { Trichostrongylus colubriformis } \\
\text { Cooperia punctata } \\
\text { Fasciola hepatica } \\
\text { Toxocara vituloru } \\
\text { Ascaris spp. } \\
\text { Taenia spp. } \\
\text { Strongylus spp. } \\
\text { Dictyocaulus spp. } \\
\text { Dicrocoelium spp. } \\
\text { Moniezia spp. } \\
\text { Oesophagostomum spp. }\end{array}$ \\
\hline Protozoa & $\begin{array}{l}\text { Giardia spp. } \\
\text { Cryptosporidium spp. } \\
\text { Eimeria spp. } \\
\text { Balantidium spp. }\end{array}$ & & \\
\hline
\end{tabular}


Table 6 Pathogens of the most prevalence, infectiousness or importance found in sludge

\begin{tabular}{|c|c|c|c|}
\hline Pathogen & Disease caused & Additional information & Reference \\
\hline E. coli strains (STEC, EHEC, EIEC, EPEC, ETEC) & $\begin{array}{l}\text { Enteric and diarrheal } \\
\text { diseases, urinary tract } \\
\text { infections, } \\
\text { sepsis/meningitis }\end{array}$ & $\begin{array}{l}6619 \text { confirmed cases of } \\
\text { severe foodborne disease } \\
\text { infections in EU/EEA in } \\
2016\end{array}$ & Ram et al. (2007), WHO (2018) \\
\hline Salmonella species (mostly Salmonella enterica) & $\begin{array}{l}\text { Salmonellosis, asymptomatic } \\
\text { infection, gastroenteritis } \\
\text { or typhoid fever }\end{array}$ & $\begin{array}{l}\text { Global non-typhoid salmo- } \\
\text { nella cases estimated for } \\
200 \text { million to } 1.3 \text { billion, } \\
\text { with possible } 3 \text { million } \\
\text { deaths a year in } 2007\end{array}$ & Coburn et al. (2007), Mumy (2014) \\
\hline Shigella (S. dysenteriae is the most severe) & $\begin{array}{l}\text { Shigellosis, gastroenteritis } \\
\text { with dysentery }\end{array}$ & $\begin{array}{l}\text { A total of } 80 \text { million cases } \\
\text { occurred with } 700,000 \\
\text { deaths a year, calculated in } \\
2005\end{array}$ & WHO (2005) \\
\hline Enteroviruses (most significant Poliovirus) & $\begin{array}{l}\text { Multiple, i.e. hand, foot and } \\
\text { mouth disease, } \\
\text { poliomyelitis, Bornholm } \\
\text { disease, polio-like } \\
\text { syndrome, pericarditis, } \\
\text { myocarditis }\end{array}$ & $\begin{array}{l}\text { A total of } 57,628 \text { cases } \\
\text { occurred with } 3,145 \\
\text { deaths and } 21,269 \\
\text { paralysed patients, in } \\
\text { 1952, in the United States }\end{array}$ & Zamula (1991) \\
\hline Vibrio cholerae & Cholera & $\begin{array}{l}\text { A total of } 1,041,422 \text { cases } \\
\text { occurred with } 9642 \text { deaths } \\
\text { in } 1991 \text { in America }\end{array}$ & Skowron et al. (2018) \\
\hline Clostridia (mostly C. perfringens) & $\begin{array}{l}\text { Type A food poisoning, } \\
\text { necrotising enteritis, } \\
\text { enterotoxaemias, } \\
\text { bacteraemia, gas gangrene }\end{array}$ & $\begin{array}{l}\text { Widely distributed in the soil } \\
\text { and in faeces of humans } \\
\text { and animals, dominant } \\
\text { cause of food poisoning in } \\
\text { the USA and Canada }\end{array}$ & $\begin{array}{l}\text { Labbe and Juneja (2017), } \\
\text { McClane (2014) }\end{array}$ \\
\hline Cryptococcus (mostly Cryptococcus neoformans) & $\begin{array}{l}\text { Meningitis, } \\
\text { meningoencephalitis or } \\
\text { disseminated disease }\end{array}$ & $\begin{array}{l}\text { Major life-threatening fungal } \\
\text { infection in patients with } \\
\text { severe HIV infection, may } \\
\text { complicate organ } \\
\text { transplantation, reticulo- } \\
\text { endothelial malignancy, } \\
\text { corticosteroid treatment or } \\
\text { sarcoidosis }\end{array}$ & Kaplan et al. (2002) \\
\hline Roundworms (mostly Ascaris lumbricoides) & $\begin{array}{l}\text { Helminthiasis (incl. } \\
\text { soil-transmitted): } \\
\text { ascariasis, necatoriasis, } \\
\text { cestodiasis, also } \\
\text { malnutrition, anaemia, and } \\
\text { others }\end{array}$ & $\begin{array}{l}\text { Ascariasis classified as the } \\
\text { most prevailing parasitic } \\
\text { infection, about } 1 / 5 \text { of the } \\
\text { world's population affect- } \\
\text { ed }\end{array}$ & $\begin{array}{l}\text { Amoah et al. (2018), } \\
\text { Vieira Da Rocha et al. (2016) }\end{array}$ \\
\hline Giardia (G. lamblia) & Giardiasis, severe diarrhoea & $\begin{array}{l}\text { About } 1 / 3 \text { of the developing } \\
\text { countries population } \\
\text { affected, from } 3 \text { to } 7 \% \text { of } \\
\text { people affected in the } \\
\text { USA }\end{array}$ & Auerbach (2011) \\
\hline
\end{tabular}

Where $b$ is the number of surviving microorganisms, $b_{0}$ is the initial number of microorganisms present and $D$ is the dose absorbed by the microorganism. The measured $D_{10}$ values for a number of microorganisms are shown in Table 7.

Determination of the applied dose for the sewage sludge treatment purpose is therefore related to microorganisms' presence. Identification of the pathogen with the highest $D_{10}$ allows the choice of the minimum radiation dose (lowest cost) that guarantees sufficient microbicidal effect.

\section{Technical aspects of sewage sludge electron beam irradiation}

\section{Electron beam accelerator-principle of operation}

Particle acceleration is an act of propelling the charged particles. For an electron beam accelerator, this particle is an electron which is negatively charged. There are three main components of the electron beam accelerator: electrons source, accelerating structure and delivery system (Hamm and Hamm 2012). 
Table $7 D_{10}$ value of various microorganisms

\begin{tabular}{|c|c|c|}
\hline Microorganism & $D_{10}$ value (kGy) & Reference \\
\hline Absidia sp. & $\leq 6$ & Maruthi et al. (2013) \\
\hline Acinetobacter radioresistens & $1.3-2.2$ & van Gerwen et al. (2016) \\
\hline Ascaris lumbriccoides & $\leq 0.45$ & Maruthi et al. (2013) \\
\hline Aspergillus fumigatus & 0.6 & Garcia et al. (1987) \\
\hline Aspergillus niger & 0.5 & van Gerwen et al. (2016) \\
\hline Bacillus pumilus & 1.4 to 1.8 & van Gerwen et al. (2016) \\
\hline Bacillus subtilis & 0.6 & van Gerwen et al. (2016) \\
\hline Brucella abortus & 0.15 & Somers (2004) \\
\hline Campylobacter sp. & $<0.2$ & Somers (2004) \\
\hline Candida albicans & 0.9 & Garcia et al. (1987) \\
\hline Clostridium botulinum & 1.4 to 4.2 & van Gerwen et al. (2016) \\
\hline Clostridium difficile & 0.9 & Garcia et al. (1987) \\
\hline Clostridium sporogenes & 1.6 to 2.2 & van Gerwen et al. (2016) \\
\hline Clostridium tetani & 2.4 & van Gerwen et al. (2016) \\
\hline Cryptococcus albidus & 2.7 & Moreira et al. (2012) \\
\hline Cryptococcus laurentiii & 3.1 to 4.5 & Maruthi et al. (2013), Moreira et al. (2012) \\
\hline Cryptococcus uniguttilans & 1.4 & Moreira et al. (2012) \\
\hline Escherichia coli & $0.3-0.4$ & Borrely et al. (1998), Sommers and Boyd (2006) \\
\hline Klebsiella pneumonia & $0.12-0.28$ & Gautam et al. (2015) \\
\hline Lactobacillus brevis & 1.2 & van Gerwen et al. (2016) \\
\hline Listeria monocytogenes & 0.62 & Rajkowski (2016) \\
\hline Micrococcus radiodurans & 2.2 & van Gerwen et al. (2016) \\
\hline Mycobacterium fortuitum & 0.6 & Garcia et al. (1987) \\
\hline Mycobacterium tuberculosis & 0.3 & Borrely et al. (1998) \\
\hline Pseudomonas spp. & 0.06 & van Gerwen et al. (2016) \\
\hline Poliovirus & 1.85 & Borrely et al. (1998) \\
\hline Saccharomyces cerevisiae & 0.5 & van Gerwen et al. (2016) \\
\hline Salmonella muenster & 0.6 & Garcia et al. (1987) \\
\hline Salmonella sp. & 0.6 & Somers (2004) \\
\hline Salmonella typhimurium & 0.2 to 1.3 & van Gerwen et al. (2016) \\
\hline Shigella dysenteriae & 0.6 & Borrely et al. (1998) \\
\hline Staphylococcus aureus & $0.2-0.5$ & Somers (2004), van Gerwen et al. (2016) \\
\hline Streptococcus faecalis & 1.56 & Garcia et al. (1987) \\
\hline Yersinia enterocolitica & 0.2 & Somers (2004) \\
\hline Vibrio cholerae & 0.48 & Borrely et al. (1998) \\
\hline
\end{tabular}

The electrons are released from a cathode via thermionic emission and the beam density is dependent on the temperature and cathode material properties (Zimek 1998). The cathode is usually the most crucial part of the electron source and its lifespan is defined by the cathode quality. After emission from the cathode, the electrons are accelerated towards the anode, which is positively charged, under the influence of a force $\left(F_{\mathrm{e}}\right)$ created by the electric field (Zimek 1998):

$F_{e}=q \times E_{\mathrm{d}}$
Where $q$-particle charge, for electron $1.602 \times 10^{-19}[\mathrm{C}]$; and $E_{\mathrm{d}}$-density of electrical field $\left[\frac{V}{m}=\frac{N}{C}\right]$.

The main difference amongst EB accelerators types is the method of electric field generation, and three main categories can be identified: high voltage direct current (DC), radio frequency (RF) and microwave linear accelerators (LINACs). Direct current acceleration involves putting the electrons through the voltage drop to give the particles the necessary velocity. There are many technical developments in this widespread EB category, but all of them require a high 
voltage supply (Chao and Chou 2017). The most important representatives of these category in relation to wastewater treatment are dynamitron, insulating core transformer (ICT) and coreless transformer (ELV) models. Radio frequency accelerators operate on the basis of the large, single volume called a resonance cavity, which is fed by radio waves (oscillating electromagnetic fields). There are two main installation within this category: the ILU- and Rhodotron-type devices. Excluding the ILU accelerator (also a linear device), LINACs are built from several small coupled copper cavities for resonating at microwave frequencies, and two main bands may be distinguished: L-band for 1-2 GHz and S-band for 2$4 \mathrm{GHz}$ (Hamm and Hamm 2012). The cavities gain energy from the microwave generator, klystron or magnetron (Chao and Chou 2017). A detailed comparison can be found in Table 8 .

Current technical developments and trends in electron beam accelerators favour the more widely researched DC systems based on the well-proven ELV and Dynamitron technology. Moreover, smaller, more compact and self-shielded devices are desirable, if possible. The RF Rhodotrons and microwave LINACs are also being extensively developed, but they are significantly more expensive and space-consuming so their application for sewage sludge treatment only is not economically justified.

\section{Electron beam irradiation parameters}

The numerous chemical parameters that affect the electron beam irradiation have been addressed in detail in the previous sections. However, there are also some technical features of the accelerator itself and the treatment process, which have implications for the implementation of the technology on the industrial scale. These are as follows (Borrely et al. 1998; Kurucz et al. 1991; Capodaglio 2017; Farooq et al. 1992; Hossain et al. 2018; International Atomic Energy Agency 2005; Kurucz et al. 1995; Nickelsen et al. 1994; Skowron et al. 2013; Trump et al. 1984; William et al. 2001):

Accelerating voltage $[\mathrm{V}]$
Electron beam power $[\mathrm{kW}]$

Electron beam current $[\mathrm{mA}]$

Applied dose [kGy]

Exposure time [s]

There are relationships between groups of these parameters. The applied voltage determines the energy of the accelerated electrons, which is usually expressed in $\mathrm{MeV}$ and $1 \mathrm{MeV}=1.602 \times 10^{-13} \mathrm{~J}$ (Kurucz et al. 1991). The direct correlation between the power, beam current, and electron energy is usually described according to the following equation:

$P=U \times I$

Where $P$ is power $[\mathrm{kW}], U$ is the energy of the electrons $[\mathrm{MeV}]$ and $I$ is the beam current $[\mathrm{mA}]$.

The electron beam dose depends on the beam power and the exposure time and is the key parameter upon which the pollutant decomposition efficiency depends. When relatively low accelerating voltage is implemented, the exposure time and/or the beam current has to be increased in order to maintain the efficiency of removal. The overall accelerator capital cost increases with both the accelerating voltage and the beam current (not to confuse with waste unit treatment cost). The running cost depends on power, as this determines the electricity requirement. The efficiency for converting electrical power into beam power depends on the accelerator technology but is in the range of 60-80\% (International Atomic Energy Agency 2005).

The decrease in pollutant concentration during the treatment might be expressed exponentially as a first-order chemical kinetics reaction, using the formula (Takács et al. 2007; Wang and Chu 2016):

$X=X_{0} \times \mathrm{e}^{-k D}$

Where $X(\mathrm{~mol} / \mathrm{l})$ is the solute concentration at the applied dose $D(\mathrm{~J} / \mathrm{kg}), X_{0}(\mathrm{~mol} / \mathrm{l})$ is the initial solute concentration and $k(\mathrm{~kg} / \mathrm{J})$ is the dose constant representing the reaction rate, i.e.

Table 8 Comparison of accelerator types (Chao and Chou 2017; Cleland 2006; Hamm and Hamm 2012; Zimek 1998)

\begin{tabular}{llll}
\hline Accelerator type & Accelerator model & Principle of operation & Capability [MeV] \\
\hline Direct current & Cockcroft-Walton & Capacitive, series-coupled & Up to 5 \\
& Dynamitron & Capacitive, parallel-coupled & 0.5 to 5 \\
& Insulating core transformer (ICT) & Magnetic, series-coupled & $0.3-3$ \\
& Coreless transformer (ELV) & Magnetic, parallel-coupled & $0.2-2.5$ \\
& Van de Graaf & Positive charge-carrying belt & $1-10$ \\
Radio frequency & ILU-type & One pass along the axis of the toroidal cavity & Up to 5 \\
Microwave linear & Rhodotron-type & Multiple passes within the coaxial cavity & $5-10$ \\
\hline
\end{tabular}


the amount of solute reduced per unit of the irradiation energy absorbed. It is possible to calculate the $k$ constant from measurements, and it is related to the solution $\mathrm{pH}$, the molecular structure of the pollutant, the water matrix, and the presence of some inorganic anions as well as radical scavengers (Le Caër 2011; Shin and Kang 2003; Takács et al. 2007; Wang and Chu 2016).

\section{Continuous slowing down approximation range of the electrons}

The first consideration regarding an e-beam irradiation installation for both wastewater and sludge sterilisation is the energy of the applied electrons. To reduce the operation cost, it should be as low as possible (Sabharwal 2013). However, that energy determines the penetration depth of the electrons (or the range of the electrons). This parameter is critical when relatively high pollutant destruction effectiveness is required in one pass (William et al. 2001). The shape of the energy deposition curve as a function of depth is presented below (Fig. 2). The electrons range defined as the continuous slowing down approximation range (CSDA) in pure water is shown in Table 9. Note that the maximum energy that can be used is $10 \mathrm{MeV}$, as above this, the electron beam can start to activate the material.

It is possible to determine the most beneficial depth of the sample for electron beam irradiation, where the value of absorbed energy reaches a peak (Fig. 2). The electron deposits its energy by interacting with atomic electrons (elastic and inelastic interactions; Krumeich 2018) and that loss depends on the energy of the electron and the time spent around the ion. Doses at the surface are relatively high, reaching 80$100 \%$ of the maximum energy absorbed (Strydom et al.

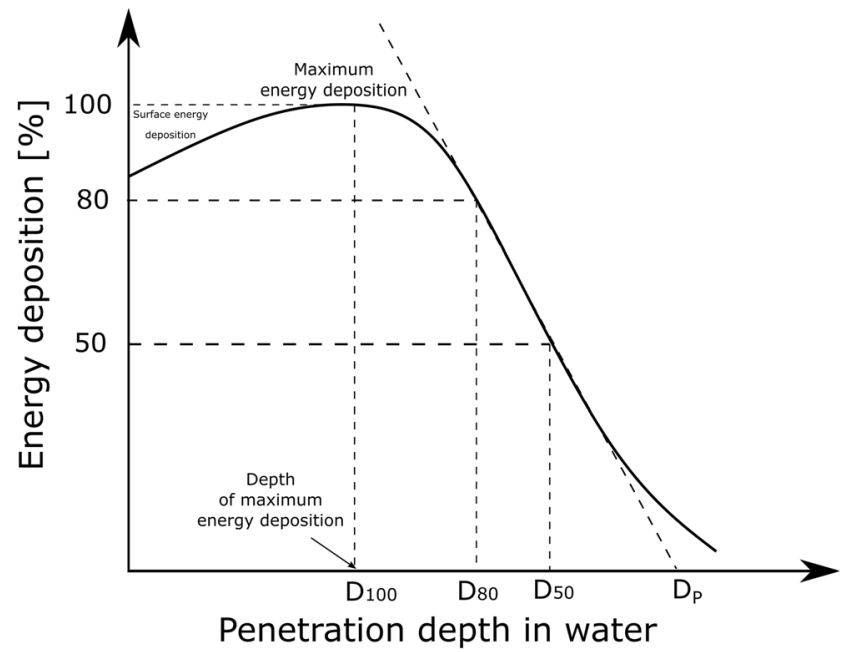

Fig. 2 The energy deposition curve as a function of penetration depth, where $D_{100}$ is the depth of maximum energy deposition, $D_{80}$ is the depth of $80 \%$ energy deposition and $\mathrm{D}_{\mathrm{P}}$ (or MPD) is the maximum penetration depth (based on Gann et al. 2004; Kurucz et al. 1995; Strydom et al. 2006)
Table 9 CSDA range and total stopping power for electrons of various energies in pure water $\left(20^{\circ} \mathrm{C}\right.$ ) (data from the National Institute of Standards and Technology 2018)

\begin{tabular}{lll}
\hline $\begin{array}{l}\text { The energy of the } \\
\text { accelerator }[\mathrm{MeV}]\end{array}$ & $\begin{array}{l}\text { Total stopping power } \\
{[\mathrm{MeV} / \mathrm{cm}]}\end{array}$ & $\begin{array}{l}\text { CSDA range } \\
{\left[\mathrm{g} / \mathrm{cm}^{2}\right]}\end{array}$ \\
\hline 0.1 & 4.119 & 0.01 \\
0.5 & 2.041 & 0.18 \\
1 & 1.862 & 0.44 \\
2 & 1.85 & 0.98 \\
3 & 1.889 & 1.51 \\
4 & 1.931 & 2.04 \\
5 & 1.971 & 2.55 \\
6 & 2.01 & 3.05 \\
7 & 2.047 & 3.55 \\
8 & 2.082 & 4.03 \\
9 & 2.116 & 4.51 \\
10 & 2.149 & 4.98 \\
\hline
\end{tabular}

2006). Along with the energy loss, deceleration occurs, and time spent in the nearest area of nuclei increases, which results in a relatively larger energy deposition. However, as a significant amount of energy has been already lost, the absolute deposition is less. The optimal solution for these two contradictory processes can be seen as a peak in the energy deposition as a function of the sample depth. The maximum dose occurs at a specific distance called depth of maximum dose $D_{100}$ (Fig. 2). Furthermore, since the approximate density of the water at the temperature of $20^{\circ} \mathrm{C}$ is $1 \mathrm{~g} / \mathrm{cm}^{3}$, the MPD of electrons $[\mathrm{cm}]$ may be determined directly from the CSDA $\left[\mathrm{g} / \mathrm{cm}^{2}\right]$ range plot. The relationship between the CSDA range, MPD and material density is given below:

$M P D=\frac{C S D A}{d}$

Where $d$ is the sludge density $\left[\mathrm{g} / \mathrm{cm}^{3}\right]$.

The higher the initial energy of the electron beam is, the deeper the dose can be delivered. When the CSDA range is expressed in the uniform unit of $\mathrm{g} / \mathrm{cm}^{2}$, it only slightly depends on the type of material.

\section{The density of the irradiated material}

In the energy range between $100 \mathrm{keV}$ and $10 \mathrm{MeV}$, the maximum penetration depth is proportional to the beam energy but inversely proportional to the density of the material to be treated ( (8).

Since the sludge as well as the anaerobic digestate (Gerber and Schneider 2015) consists of solids and water, the content of total solids (TS) is the primary parameter upon which the average density of sludge depends. However, the density at the most stages of their treatment is similar to water 
Table 10 Sludge density relation to total solids content in sludge (based on Fernandes et al. 2007)

\begin{tabular}{|c|c|c|c|c|c|c|c|}
\hline \multirow[t]{3}{*}{ Types of sludge } & \multirow[t]{3}{*}{$\% \mathrm{TS}$} & \multirow{2}{*}{\multicolumn{2}{|c|}{ Density of sludge $\left(\mathrm{g} / \mathrm{cm}^{3}\right)$}} & \multicolumn{4}{|c|}{ MPD $[\mathrm{cm}]$} \\
\hline & & & & \multicolumn{2}{|c|}{$2 \mathrm{MeV}$} & \multicolumn{2}{|c|}{$10 \mathrm{MeV}$} \\
\hline & & Min & Max & Max & Min & Max & Min \\
\hline Primary sludge & $2.0-6.0$ & 1.003 & 1.01 & 0.98 & 0.97 & 4.96 & 4.93 \\
\hline Thickened mixed sludge & $3.0-8.0$ & 1.004 & 1.01 & 0.97 & 0.97 & 4.96 & 4.93 \\
\hline Primary thickened sludge & $4.0-8.0$ & 1.006 & 1.01 & 0.97 & 0.97 & 4.95 & 4.93 \\
\hline Digested mixed sludge & $3.0-6.0$ & 1.007 & 1.02 & 0.97 & 0.96 & 4.94 & 4.88 \\
\hline Secondary anaerobic sludge & $3.0-6.0$ & 1.01 & 1.02 & 0.97 & 0.96 & 4.93 & 4.88 \\
\hline Dewatered sludge & $20.0-40.0$ & 1.05 & 1.1 & 0.93 & 0.89 & 4.74 & 4.52 \\
\hline
\end{tabular}

(Fernandes et al. 2007; Sperling 2005) and typical values vary from $1.02 \mathrm{~g} / \mathrm{cm}^{3}$ for liquid sludge to $1.1 \mathrm{~g} / \mathrm{cm}^{3}$ for dewatered sludge (Fernandes et al. 2007; Sperling 2005). The MPD values for different sludge densities are shown in Table 10. Due to the small differences in density, there are only relatively small changes in the MPD, indicating that the same beam energy can be used for different types of sludge.

\section{General sewage sludge composition}

As has been adduced before, there are many specific compounds in sewage sludge, which have a significant influence on the treatment process (free radical scavengers, PPCPs, POPs- "Free radical scavengers" section; hydroxide and oxonium ions-" $\mathrm{pH}$ influence" section). Nevertheless, there are also some general categories of sewage sludge components, reacting differently when undergoing the electron beam treatment.

Using one of the most common wastewater quality indicators, chemical oxygen demand, the total organic matter can be divided into biodegradable (BCOD) and an inert (nonbiodegradable) fraction (ICOD) (Orhon and Cokgor 1997). The biodegradable part can be further subdivided into readily biodegradable (RBCOD) and slowly/particulate biodegradable (SBCOD). The non-biodegradable fraction has two major components: soluble (ISCOD) and particulate (IPCOD). Therefore, the total COD can be represented accordingly (9, Fig. 3) (Choi et al. 2017; Myszograj et al. 2017; Orhon and Cokgor 1997):

$\mathrm{COD}=\mathrm{RBCOD}+\mathrm{SBCOD}+\mathrm{IPCOD}+\mathrm{ISCOD}\left[\mathrm{g} \mathrm{O}_{2} / \mathrm{m}^{3}\right]$

The RBCOD refers to matter that can be quickly and easily degraded by microorganisms, like volatile fatty acids or leachate from municipal landfills, whereas SBCOD decomposition is slow, caused by various microbial metabolism processes (Choi et al. 2017). Both RBCOD and SBCOD have to be hydrolysed prior to destruction (Myszograj et al. 2017). The IPCOD fraction is insoluble and impossible to decompose by microorganisms, but it is effortlessly removable by sedimentation, while the ISCOD poses a serious challenge to traditional WWTPs as it usually means the presence of such persistent pollutants as organic, aromatic compounds (benzene, toluene, other substances with a benzene ring).

Multiple and sometimes inconsistent information have been reported regarding the EB influence on both BOD and COD of the sewage sludge. Many researchers reported the COD to be only slightly changed after the irradiation
Fig. 3 Distribution of chemical oxygen demand fractions in sewage sludge (based on Choi et al. 2017; Myszograj et al. 2017; Orhon and Cokgor 1997)

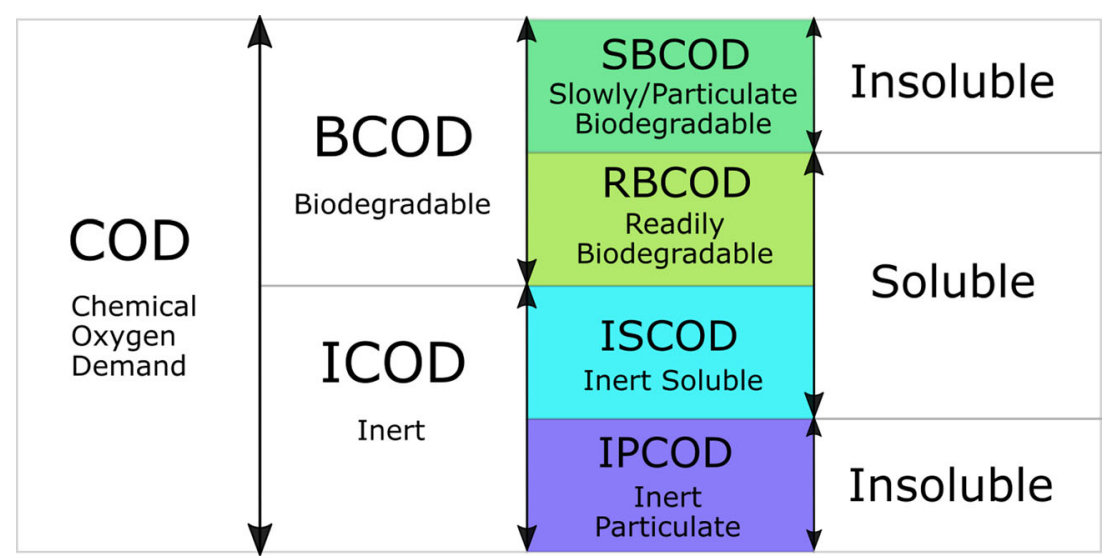




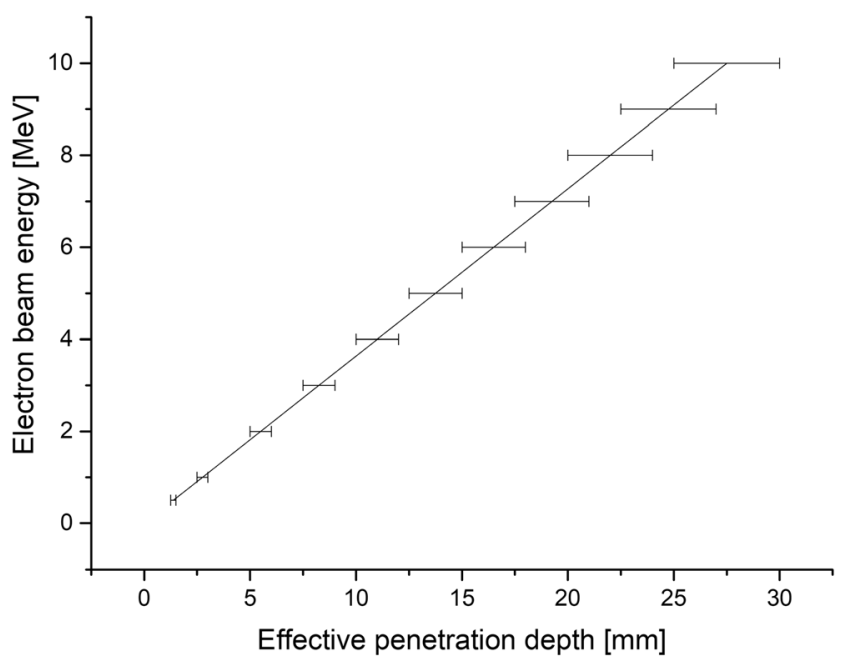

Fig. 4 The effective penetration of the electrons into the sewage sludge within the 1-10-MeV range (Alcántara and Cruz 1997)

(Farooq et al. 1992; Kim et al. 2007; Zheng et al. 2001), while others noted significant growth in soluble COD parameter (Changqing and Min 2012; Park et al. 2009), reaching $2400 \%$ increase, when the EB at $6 \mathrm{kGy}(1 \mathrm{MeV}$ ELV-4 Model, Pyrex tray $35 \times 22.5 \times 5.6 \mathrm{~cm}$ ) was applied as the sludge anaerobic digestion pretreatment (Shin and Kang 2003). Nonetheless, the considerable changes were only observed in the SCOD part. Therefore, it can be indicated that using the EB, the insoluble part of the COD can be converted, increasing the SCOD contribution but not changing the overall COD value.

It is not possible now to explicitly determine the EB influence on BOD as there are both reports on its increase (Kim et al. 2007; Paul et al. 2011) and decrease (Han et al. 2012; He et al. 2016), and this issue should be investigated further.

\section{Sewage sludge thickness}

Given the fact that the ability of electrons for sludge matrix penetration is one of the most important parameters on which e-beam system efficiency depends, the optimal technical solution of sludge delivery system should be implemented. Therefore, it requires an accordingly thin layer of waste to be irradiated (Fig. 4). Various options of such technology have been examined so far, both continuous and batch. The summary of the layouts reported so far can be found in Table 11 .

Batch layout was usually applied during laboratory tests, and various sludge thickness options were provided in accordance to the available accelerator. In general, there have been two different ways of continuous sludge delivery system so far: sludge cascade using gravity (Engohang-Ndong et al. 2015; Kurucz et al. 1995; Trump et al. 1984; Waite et al. 1985) (Fig. 5) and a mechanical conveyor belt, usually with the nozzle-type injector (Kim et al. 2007, 2009; Mckeown 1996; Shin et al. 2002) (Fig. 6 and Fig. 7). It can be clearly seen that the crucial factor during the low-energy EB application is material thickness as the MPD in pure water for $1 \mathrm{MeV}$ is only $0.44 \mathrm{~cm}$. Nevertheless, the effective penetration of the electrons into the sewage sludge is claimed to be only about 2.5-3.0 $\mathrm{mm}$ per $1 \mathrm{MeV}$ (Alcántara and Cruz 1997) due to the presence of several scavengers, and the relationship between the sludge thickness and energy can be introduced linearly as (10, Fig. 4):

Table 11 Sewage sludge irradiation layouts reported so far. Best results, if determined, are presented in italics

\begin{tabular}{|c|c|c|c|c|}
\hline Process layout & $\begin{array}{l}\text { EB energy } \\
{[\mathrm{MeV}]}\end{array}$ & $\begin{array}{l}\text { Treatment dose } \\
{[\mathrm{kGy}]}\end{array}$ & $\begin{array}{l}\text { Sludge thickness [cm] } \\
\text { and/or throughput [per min] }\end{array}$ & Reference \\
\hline \multirow[t]{5}{*}{ Batch } & 1.8 & $2-20$ & $0.3-1(0.5)$ & Changqing and Min (2012) \\
\hline & 1 & $0.5-6$ & 5.6 & Shin and Kang (2003) \\
\hline & 1 & $1-7$ & $0.25-1$ & Park et al. (2009) \\
\hline & 10 & $0.2-10$ & Not determined, probably $<0.5 \mathrm{~cm}^{\mathrm{a}}$ & Praveen et al. (2013) \\
\hline & 10 & $1-10$ & Not determined, probably $<1 \mathrm{~cm}^{\mathrm{b}}$ & (Skowron et al. (2013) \\
\hline \multirow[t]{3}{*}{ Continuous sludge cascade } & 3 & $2.7-30.7$ & Not determined, sludge flow $113 \mathrm{l} / \mathrm{min}$ & Engohang-Ndong et al. (2015) \\
\hline & 1.5 & 4 & $\sim 0.38$, sludge flow $460 \mathrm{1} / \mathrm{min}$ & Kurucz et al. (1995), Waite et al. (1985) \\
\hline & 1.5 & 4 & Not determined, sludge flow $450 \mathrm{l} / \mathrm{min}$ & Trump et al. (1984) \\
\hline \multirow{5}{*}{$\begin{array}{l}\text { Continuous, conveyor belt, } \\
\text { with the nozzle-type injector }\end{array}$} & 2.5 & 10 & 0.7 , sludge flow $8.3 \mathrm{~kg} / \mathrm{min}$ & Kim et al. (2009) \\
\hline & 1 & $1-3$ & 0.4 , sludge flow $40 \mathrm{l} / \mathrm{min}$ & Shin et al. (2002) \\
\hline & 10 & $5-7$ & $2.5-3$, sludge flow $48.6 \mathrm{~kg} / \mathrm{min}$ & Chmielewski et al. (1995) \\
\hline & 10 & $5-15$ & Not determined, sludge flow $67.4 \mathrm{~kg} / \mathrm{min}$ & Mckeown (1996) \\
\hline & 2 & $2-5$ & $0.1-1,5 \mathrm{~kg} / \mathrm{min}$ & Takeshita and Naramoto (1992) \\
\hline
\end{tabular}

${ }^{\text {a }}$ Samples triple bagged in Whirl-Pak ${ }^{\circledR}$ bags $(12.5 \mathrm{~cm} \mathrm{~L} \times 7.5 \mathrm{~cm} \mathrm{~W}, 0.057 \mathrm{~mm}), 20 \mathrm{ml}$ of sludge each

${ }^{\mathrm{b}}$ Samples bagged in plastic, synthetic bags, $100 \mathrm{ml}$ of sludge each 


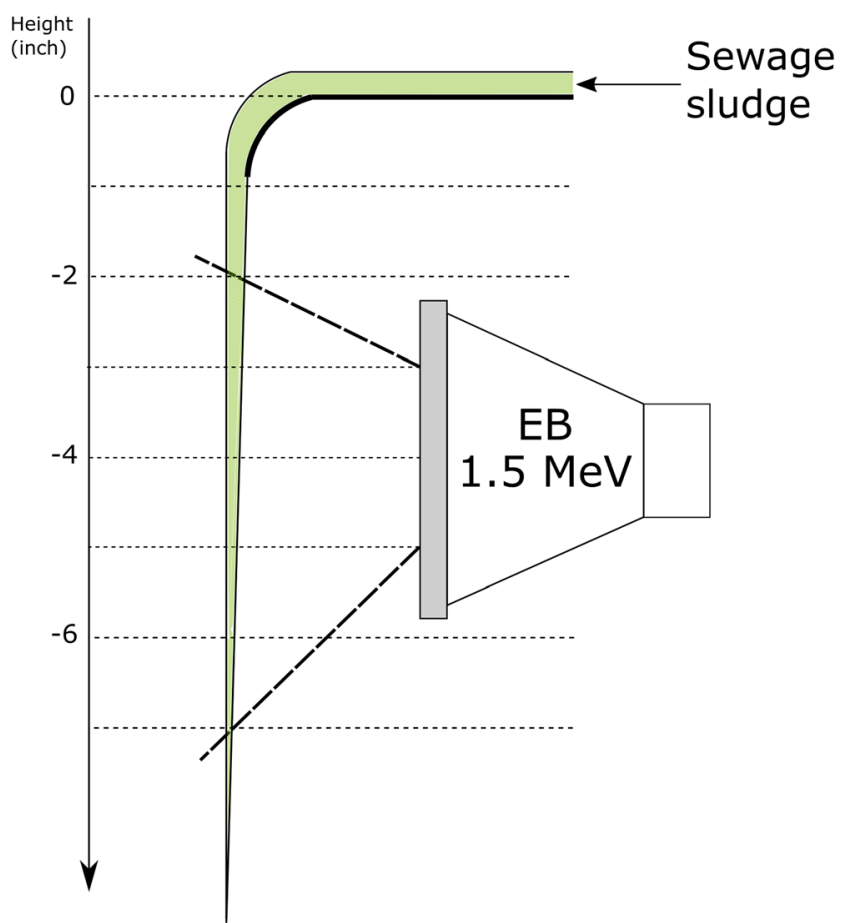

Fig. 5 The scheme of the cascade-type sludge sterilisation system (based on Waite et al. 1985). Cross-section of the sludge stream falling over the weir

$y=0.3636 x$

Where $y$-energy of the accelerator within the range 1-10 $\mathrm{MeV}$ and $x$-effective penetration depth/required sludge thickness [mm].
When a high energy accelerator might be used (MPD around $5 \mathrm{~cm}$ for $10 \mathrm{MeV}$ ), the treatment dose becomes critical since electrons can penetrate a large volume of sludge and high-dose application ensures desired sterilisation effect. The average dose absorbed by the material with the low atomic number (Z) can be described as (Zimek 1998):

$D=\frac{E \times j \times t \times 10^{6}}{\operatorname{CSDA}}$

Where $D$-dose [Gy], $E$-electron energy [MeV], $j$ beam current density $\left[\mathrm{mA} / \mathrm{cm}^{2}\right], t$ - time [s] and CSDApenetration range $\left[\mathrm{g} / \mathrm{cm}^{2}\right]$.

There were various doses tested for sludge sterilisation so far, ranging from 1 up to above $30 \mathrm{kGy}$ (Table 11), but the 10$\mathrm{kGy}$ absorption is enough for sludge to meet the U.S. EPA Guideline Class A Biosolids requirements (Kim et al. 2009; US EPA 2003).

\section{Cost-benefit analysis and dose optimisation}

One of the most important factors to consider while designing any industrial process is cost investigation for both capital and operational expenditure. Detailed analysis for various acceleration parameters is presented below (Table 12).

Despite the fact that literature lacks many examples of industrial-scale EB sludge treatment facilities, the throughput and related cost might be relatively easily scaled up for a certain accelerator type, when cost is only dependent on electricity consumption. As the EB system irradiation dose rate is directly related to beam current (11), higher currents ensure certain dose delivery in a shorter treatment time, allowing for
Fig. 6 The scheme of the nozzletype sludge sterilisation system (based on Kim et al. 2009)

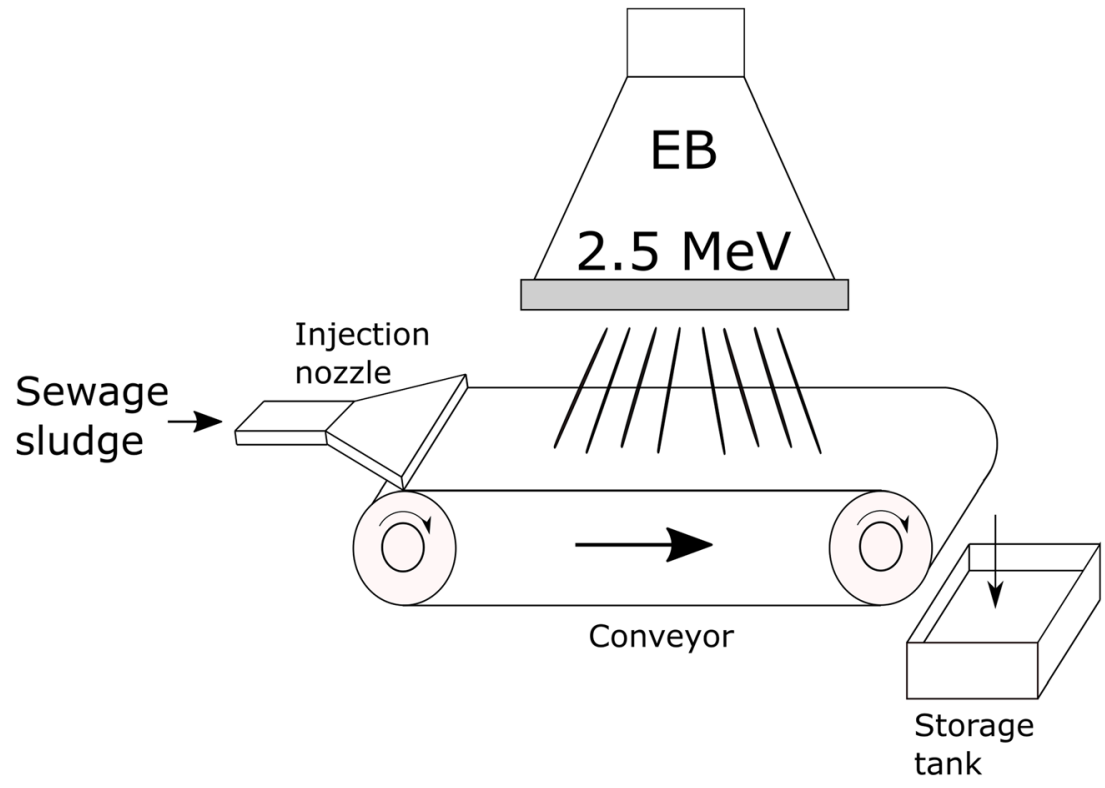




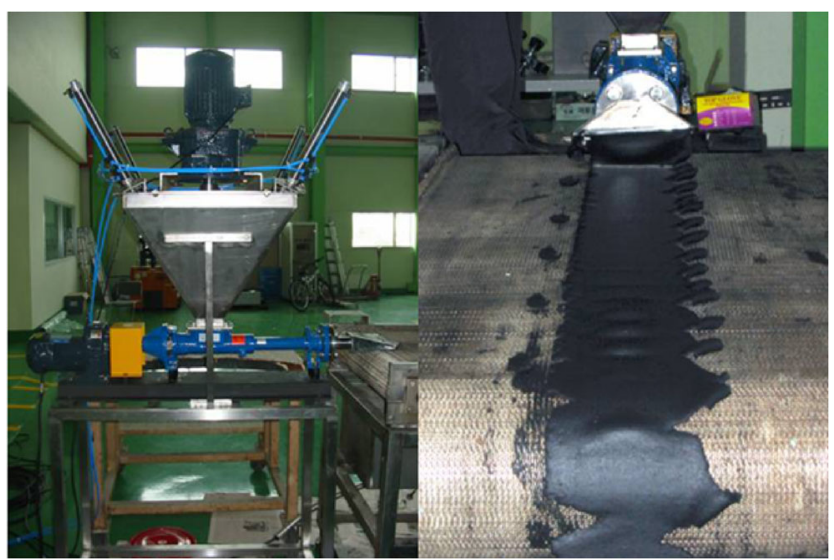

Fig. 7 The picture of nozzle-type sludge sterilisation system. Image courtesy of Kim et al. (2009)

increased waste load throughout the year and decreased cost. It can be clearly seen that for EB treatment both operating and capital costs per waste unit decrease with capacity increase, and therefore, treatment of a small amount of sludge is not competitive with currently existing methods, but the 100-mA (with 50 times higher dose rate compared to $2 \mathrm{~mA}$ ) option is much less expensive (Table 13) than any other traditional system. There is no additional treatment (such as $\mathrm{AD}$ ) required for $15 \mathrm{kGy}$ dose (Pillai and Reimers 2013).

\section{Accelerator operation}

The existing accelerator technology is not able to operate continuously, as time is required for maintenance and repairs. Most current technology can be used reliably for $16 \mathrm{~h}$ a day, 20 days per month. This means that the sewage sludge must be stored before treatment. In most plants, this will not cause any problems as storage already takes place. The technology used in the accelerators is constantly being improved and the time for which the accelerator can be operated and the reliability is being increased.

\section{Electron beam comparison with other techniques}

\section{Electron beam comparison with AD, THP and incineration}

Currently, around $84 \%$ of sewage sludge in the UK is treated by anaerobic digestion (Ofwat 2016). This technology is based on the breakdown of organic material by microorganisms in the absence of oxygen, and it has an additional advantage of producing biogas, which can be transformed into electricity and fuel in the combined heat-power plant (Mills 2015). However, anaerobic digestion is limited by relatively slow dry solids hydrolysis, and it requires large environmental footprints (Xue et al. 2015). Therefore, several improvements have been developed to make the anaerobic digestion more efficient and beneficial. The most notable of these is thermal hydrolysis process (THP). It is also common to use incineration with energy recovery, where temperatures range between 800 and $1200{ }^{\circ} \mathrm{C}$ (DEFRA 2012). There were some tests on implementing the EB before the AD unit (Park et al. 2009; Rawat and Sarma 2013; Shin and Kang 2003), but most of the studies have been done on EB radiolysis of the already anaerobically treated sludge. The list of the most important parameters of the AD itself, $\mathrm{EB}+\mathrm{AD}$ and THP $+\mathrm{AD}$ and of the incineration processes is shown in Table 13.

\section{Removal of bacteria, viruses and pathogens}

The main purpose of the sewage sludge treatment is to remove the pathogenic microorganisms so that it can be safely treated as substrate (usually fertiliser), landfilled or stored (Świerczek et al. 2018). The overall efficiency of this hygienisation for the AD, THP and EB is $99 \%$ (2 log reduction), $99.99 \%$ (4 log reduction) and $>5 \log$ reduction for $10 \mathrm{kGy} \mathrm{EB}$, respectively (Chmielewski et al. 1995; Chmielewski and Sudlitz 2019; Levantesi et al. 2015; Mills 2015; Taboada-Santos et al. 2019).
Table 12 Operational and capital costs for various EB treatment parameters (adapted from Han et al. 2012; Kim et al. 2009; Pillai and Reimers 2013)

\begin{tabular}{|c|c|c|c|c|c|}
\hline Accelerator type & $\begin{array}{l}\text { Dry solids } \\
\text { content }[\%]\end{array}$ & $\begin{array}{l}\text { Capacity } \\
\text { [TDS/year] }\end{array}$ & $\begin{array}{l}\text { Capacity } \\
{\left[\mathrm{m}^{3} / \text { day }\right]}\end{array}$ & $\begin{array}{l}\text { Operating cost } \\
\text { [\$/TDS] }\end{array}$ & $\begin{array}{l}\text { Capital } \\
\text { cost }[\$]\end{array}$ \\
\hline \multirow{2}{*}{$\begin{array}{l}\text { Dual, } \sim 2 \mathrm{~mA}, 18 \mathrm{~kW}, 10 \\
\mathrm{MeV}, 15 \mathrm{kGy}\end{array}$} & 2.6 & 7875 & 28.63 & 378 & \multirow{4}{*}{15 million } \\
\hline & 4.3 & 11,250 & 38.78 & 232 & \\
\hline \multirow{2}{*}{$\begin{array}{l}\text { Duala, } 100 \mathrm{~mA}, 50 \mathrm{~kW}, 15 \\
\text { kGy }\end{array}$} & 2.6 & 393,750 & 1332 & 6.79 & \\
\hline & 4.3 & 562,600 & 1927 & 4.75 & \\
\hline \multirow{2}{*}{$\begin{array}{l}40 \mathrm{~mA}, 100 \mathrm{~kW}, 2.5 \mathrm{MeV} \text {, } \\
10 \mathrm{kGy}\end{array}$} & $18-20$ & 15,660 & 226 & 4.4 & \multirow{2}{*}{$\begin{array}{l}1.98 \\
\text { million }\end{array}$} \\
\hline & & 33,556 & 484 & 2.2 & \\
\hline $\begin{array}{l}400 \mathrm{~mA}, 400 \mathrm{~kW}, 1 \mathrm{MeV}, \\
\quad 1 \mathrm{kGy}\end{array}$ & N/A & & 10,000 & 0.3 per $\mathrm{m}^{3 \mathrm{~b}}$ & 4 million \\
\hline
\end{tabular}

${ }^{a}$ Theoretical calculation, scaled-up from $2 \mathrm{~mA}$ scenario (Pillai and Reimers 2013)

${ }^{\mathrm{b}}$ Textile wastewater treatment plant operating in Daegu Dyeing Industrial Complex in Korea. Operating cost per $\mathrm{m}^{3}$ instead of per TDS as there are mostly liquid impurities present in textile waste (Han et al. 2012) 


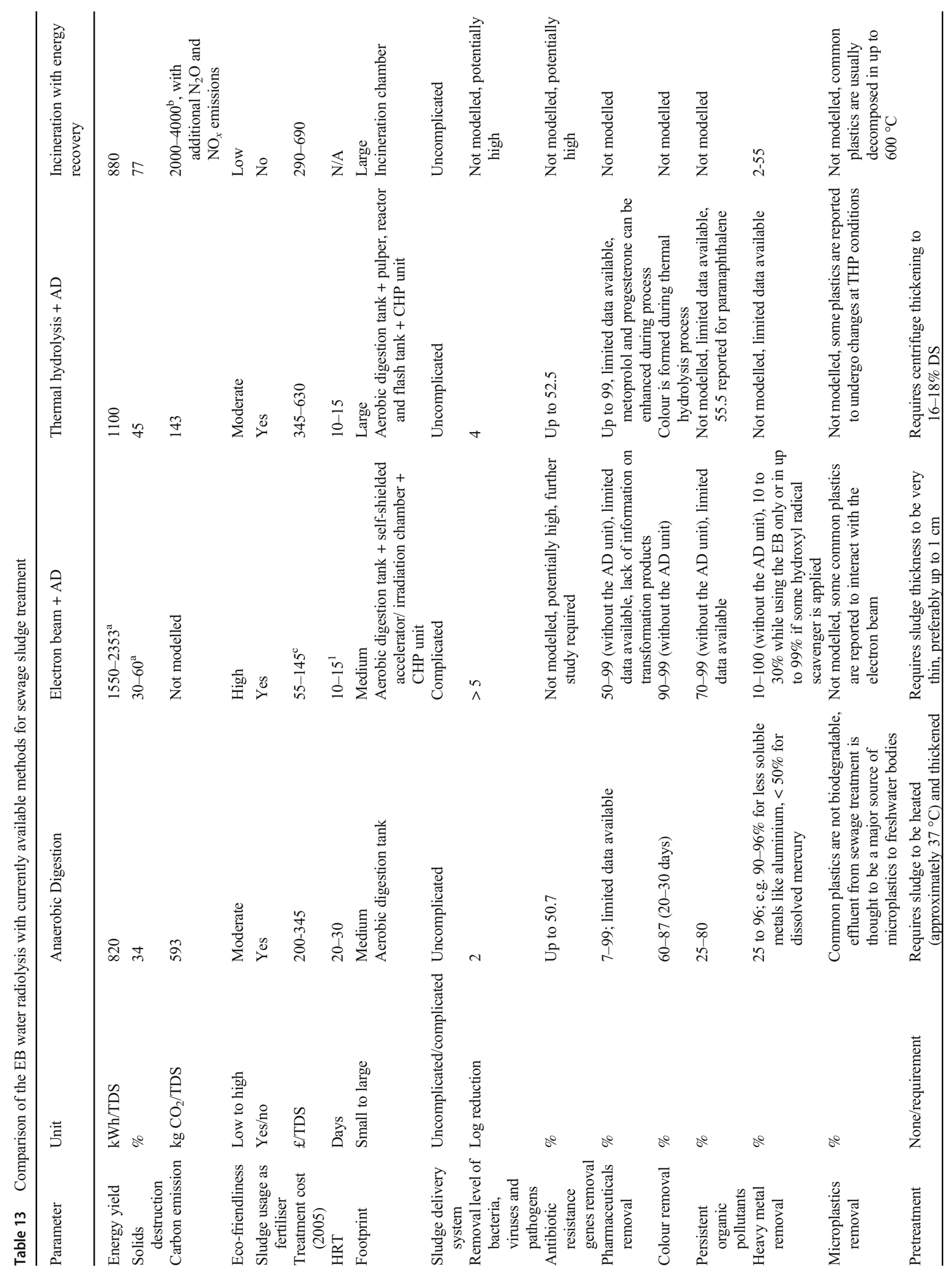




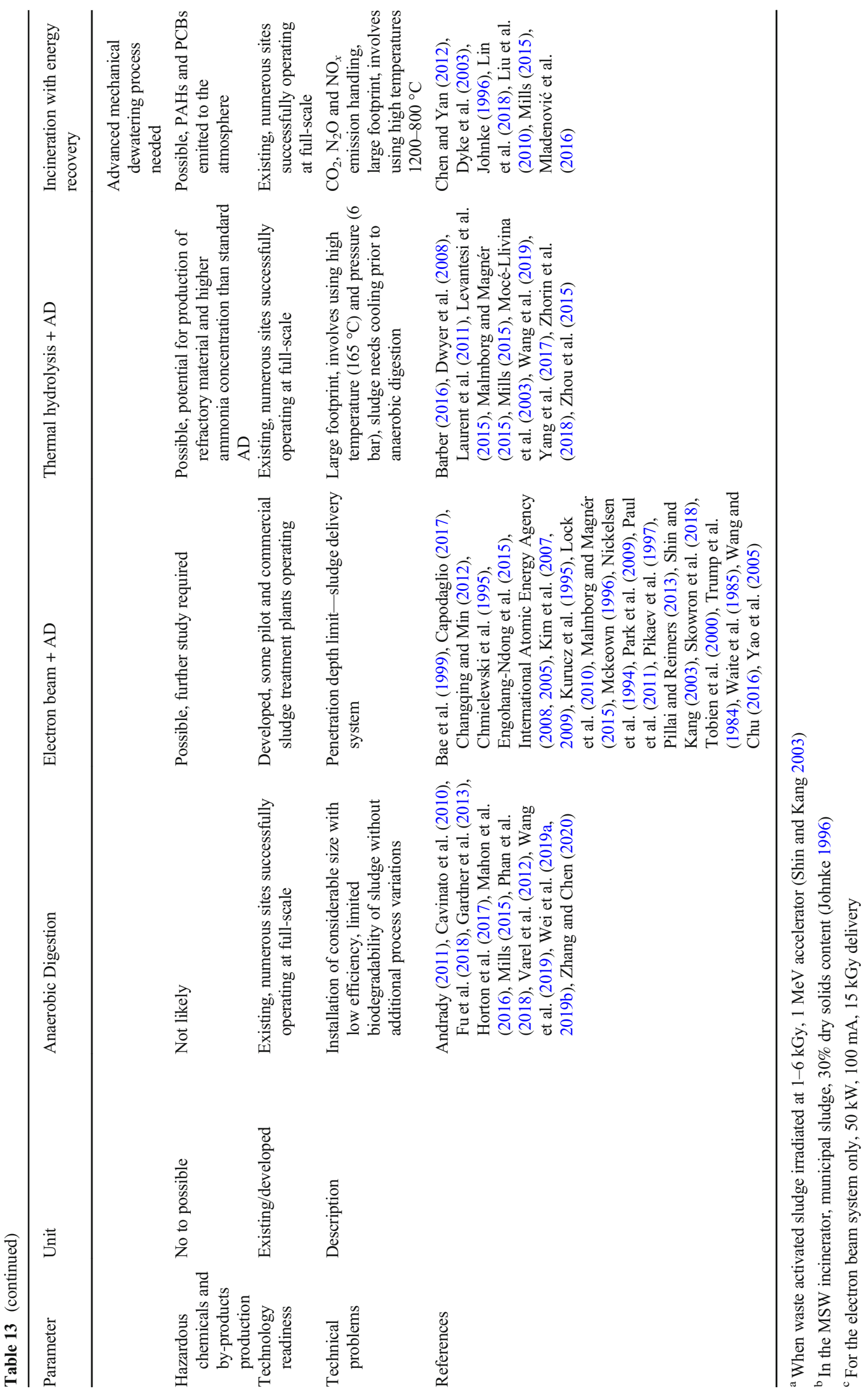


Although all of the methods have very good performance, the mechanism of pathogen removal is different for each of them. $\mathrm{AD}$ treatment is based on the combination of competitive microbial interactions, time spent in the reactor and temperature influence as well as build-up or presence of toxic metals (Appels et al. 2008). The pathogens' die-off kinetic models for these parameters are well-known and widely described in the literature (Avery et al. 2014). THP reduction in hazardous microorganisms is based on high temperature and high pressure which are applied simultaneously and are detrimental to the biological cells of pathogens and their proliferation functions, significantly increasing treatment efficiency when compared to AD only (Levantesi et al. 2015). EB hygienisation, although affected by several similar parameters like toxic metal presence, induces microorganism destruction by high energy electron penetration into the sludge and the production of radicals (see "Sewage sludge direct and indirect radiolysis" and "Influence of the presence of pathogens" sections). The incineration process involves converting sludge into gases, water and ash by extremely high temperature, which is lethal for all pathogen types but has been recognised as no longer a viable option for waste management (Greenpeace 2019).

There are multiple organisms reported to be resistant to $\mathrm{AD}$ and THP, and some pathogens can be enriched, but THP treatment is able to meet the class A biosolids requirements (Mocé-Llivina et al. 2003; Sassi et al. 2018; Wang et al. 2018; Zhao and Liu 2019). It is worth noting that the EB pathogen removal capability is only dependent on the applied dose
(Table 7), and there is no organism resistant to irradiation present in the literature. Summary of the AD, THP and EB efficiency in the removal of several microorganisms is presented in Table 14.

\section{Electron beam comparison with other irradiation techniques}

As mentioned, irradiation by electron beam for sludge hygienisation has been introduced several decades ago. Nonetheless, the ionising radiation for such treatment is not only limited to acceleration techniques (Priyadarshini et al. 2014). There are several other techniques with a similar principle of treatment and method efficiency, which uses different irradiation sources, such as alpha, beta, gamma and X-ray. Amongst them, only the gamma installations have been implemented on the industrial scale (Rathod et al. 2009). There are many gamma irradiation plants successfully operating all over the world, accounting for the majority of facilities using the ionising radiation for liquid wastewater treatment purposes (Asgari Lajayer et al. 2019).

Gamma radiation, also known as $\gamma$ rays, refers to short wavelength, high-frequency electromagnetic radiation of very high energy (photons with no charge and rest mass). It is emitted by unstable nuclei during its transition to a lowerenergy state. Given the nature of $\gamma$ rays as photons, they are also the most penetrating amongst other types of

Table 14 Compilation of log drop for different types of treatment

\begin{tabular}{|c|c|c|c|c|c|c|}
\hline Pathogen & $\mathrm{AD}$ & Reference & THP & Reference & $\mathrm{EB}(10 \mathrm{kGy})^{\mathrm{a}}$ & Reference \\
\hline Total coliforms & $0.3-3$ & Avery et al. (2014) & Unknown & - & 4 & Chmielewski et al. (1995) \\
\hline Faecal coliforms & $1.3-3.0$ & & $4^{\mathrm{b}}$ & Wang et al. (2018) & $>8$ & Chmielewski et al. (1995) \\
\hline Enterococcus & No change-1.6 & & $>2.70$ & & $>8$ & van Gerwen et al. (2016) \\
\hline C. perfringens & No change & & $0.3-2.5 \mathrm{c}$ & Carrington (2001) & $>8$ & Kim et al. (2018) \\
\hline E. coli & $1-2$ & & $3.2-5.3$ & Levantesi et al. (2015) & $>8$ & Borrely et al. (1998) \\
\hline Salmonella & $0.2-2.23$ & & $0.9-2.3$ & Levantesi et al. (2015) & $>8$ & Garcia et al. (1987) \\
\hline $\begin{array}{l}\text { Protozoa } \\
\text { Cryptosporidium }\end{array}$ & 0.3 & & $>4$ & Blewitt (1989) & $>2$ & Demirci and Ngadi (2012) \\
\hline L. monocytogenes & 2.23 & & $>4^{\mathrm{d}}$ & Environment Agency (2003) & $>8$ & Rajkowski (2016) \\
\hline C. jejuni & -1.0 & & $>5 \mathrm{~d}$ & Environment Agency (2003) & $>8$ & van Gerwen et al. (2016) \\
\hline Enteroviruses & No change-2.0 & & $>4$ & Astals et al. (2012) & $2-2.9$ & Demirci and Ngadi (2012) \\
\hline Somatic coliphage & 0.09 & & $3.9-5.2$ & Levantesi et al. (2015) & 2.5 & Praveen et al. (2013) \\
\hline Poliovirus & 6.2 & & Unknown & - & $4.4-5.4$ & Borrely et al. (1998) \\
\hline Protozoa Giardia & No change -2.0 & & $>4$ & Blewitt (1989) & $>2$ & Lenaghan (2008) \\
\hline Ascaris suum ova & No change & & $>3 \mathrm{c}$ & Carrington, (2001) & $>8$ & $\begin{array}{l}\text { Capizzi-Banas } \\
\text { and Schwartzbrod (2001) }\end{array}$ \\
\hline
\end{tabular}

\footnotetext{
${ }^{a}$ Data extrapolated for the dose required for meeting the class A biosolids efficiency (Kim et al. 2009; US EPA 2003)

${ }^{\mathrm{b}}$ Assuming that the faecal coliform concentration in untreated sewage sludge is $\sim 10^{6}$ microorganism per $100 \mathrm{ml}$ (Kim et al. 2009)

${ }^{\mathrm{c}}$ Assuming that THP complies with the class A biosolids requirements (Wang et al. 2018)

${ }^{\mathrm{d}}$ Assuming that THP has better performance than pasteurisation in $70{ }^{\circ} \mathrm{C}$ for $1 \mathrm{~h}$ (Pickworth et al. 2012)
} 
Table 15 Ionising radiation techniques for sludge hygienisation comparison: electron beam versus gamma rays (Freita-Silva et al. 2015; GIPA and iia 2017)

\begin{tabular}{|c|c|c|}
\hline Parameter & Gamma irradiation & Electron beam \\
\hline Irradiation doses & Low to medium, cannot be quickly adjusted & Medium to high, can be quickly adjusted \\
\hline Processing timea & Slow, typically $<24 \mathrm{~h}$ & Fast, typically $<8 \mathrm{~h}$ \\
\hline Operation & $\begin{array}{l}\text { Inflexible, cannot be turned off; gamma } \\
\text { rays emitted in all directions }\end{array}$ & Flexible, can be turned off; electrons aimed directly at the product \\
\hline Penetration & Excellent, high efficiency for all product types & Low, efficiency depends on product density \\
\hline Eco-friendliness & $\begin{array}{l}\text { Low, uses radioactive material that needs } \\
\text { proper disposal, necessary radionuclides } \\
\text { are produced by nuclear reactor }\end{array}$ & High, uses electricity to generate high energy electrons \\
\hline Operation cost & $\begin{array}{l}\text { Low, requires additionally gamma rays } \\
\text { source replacement and disposal annually }\end{array}$ & Low, greater demand for electricity than gamma installation \\
\hline Capital cost & $\begin{array}{l}\text { Medium, cost of irradiation source, conveyor }+ \\
\text { safety/control systems, specific and common infrastructure }\end{array}$ & $\begin{array}{l}\text { High, cost of irradiation source higher than for } \\
\text { gamma rays, conveyor + safety/control systems, } \\
\text { specific and common infrastructure }\end{array}$ \\
\hline
\end{tabular}

${ }^{\mathrm{a}}$ When the same volume of product, typical 45 - $\mathrm{ft}$ tractor trailer $\left(\sim 85 \mathrm{~m}^{3}\right)$ is treated (GIPA and iia 2017)

electromagnetic radiation and thus the most biologically hazardous (Freita-Silva et al. 2015). A gamma irradiation system involves using radioactive (self-disintegrating) isotopes, and amongst hundreds of gamma emitters, only cobalt ${ }^{60} \mathrm{Co}$ or caesium ${ }^{137} \mathrm{Cs}$ is permitted for radiation processing (da Silva Aquino 2012).

Currently, ionising radiation techniques for sludge treatment are only considered through gamma and electron beam irradiation. Both systems, although inducing water radiolysis and consequently highly reactive radical formation, have great differences that should be considered prior to irradiation treatment plant design. The up-to-date list of known $\gamma$ rays and EB features can be seen in Table 15 .

The main differences about the EB and gamma systems are penetration possibilities and irradiation generation. Due to high energy, no charge and no mass, photons can easily penetrate most of the waste both solid and liquid, while electrons can be relatively easily attenuated and dispersed by highdense matter (see "Continuous slowing down approximation range of the electrons" section). Therefore, the material to be irradiated has to be accordingly thin for EB treatment, while gamma source can penetrate as far as $120 \mathrm{~cm}$ of $0.4 \mathrm{~g} / \mathrm{cm}^{3}$ dense product (GIPA and iia 2017). Nonetheless, despite this undeniable advantage of gamma ray over EB accelerator, usage of a radioactive source, its handling and safe disposal should be considered very carefully. Electron beam technology has been improved significantly throughout the last 20 years, and it is no longer a highly expensive equipment, only available for limited use (Hossain et al. 2018). Therefore, given the current worldwide trends towards more eco-friendly, reliable and long-lived installations, it is advised to avoid technologies dependent on highly biological hazardous components, when possible (Cordella and Kaps 2018). Nevertheless, usage of gamma rays for other industries that benefit from radiation processing including medicine, food, polymers and automotive industries might be more justified due to the high-density material to be irradiated.

\section{Conclusions}

The following can be concluded from the literature:

- A microbicidal action of ionising radiation is achieved by its direct (physical) and indirect (chemical) action. Direct interaction with the organic compound may only be significant when the concentration of the contaminant is $\geq 0.1$ M. The indirect effect of irradiation is the result of free radicals forming in water that can interact with each other and with the molecules of the pollutant.

- The sensitivity of microorganisms varies significantly from one species to another. Hence, identification of the pathogens existing in the sludge to be irradiated and their lethal doses are necessary when designing the EB treatment facility. The pathogen with the highest $D_{10}$ should be determined.

- In real conditions (sewage sludge, wastewater/natural water with a complex composition), some components naturally found in water scavenge reactive chemical species produced during treatment (e.g. $\mathrm{O}_{2}, \mathrm{HCO}_{3}{ }^{-}, \mathrm{CO}_{3}{ }^{2-}, \mathrm{Cl}^{-}$, $\mathrm{NO}_{2}{ }^{-}, \mathrm{NO}_{3}{ }^{-}$) both decreasing (more likely) or increasing (less likely) overall process efficiency.

- In some cases, the addition of the non-water origin scavenger may lower the dose (cost) requirement by increasing the overall efficiency of the EB irradiation process.

- The solution $\mathrm{pH}$ has a noteworthy influence on the main water radiolysis products and their initial yields. Degradation of pollutants is favoured at weak acidic to neutral conditions. Thus, controlling of solution $\mathrm{pH}$ is a 
parameter, which may relatively easily increase the electron beam treatment efficiency and further investigation of this issue is recommended.

- The most important reactive species amongst water radiolysis products responsible for contamination removal should always be identified.

- For the EB influence on the BOD and COD parameter determination, it is necessary to investigate the content of the microorganisms and the biodegradable and inert part of the sludge as it can be critical to fully understand the chemical action of the reactive species created by accelerated electrons.

- Since such chemicals like hormones or pharmaceuticals can not only react with reactive species but also be a source of toxic by-products (transformation products), further examination of their reactions with electron beam origin radicals is highly recommended.

- Within the energy range between $100 \mathrm{keV}$ and $10 \mathrm{MeV}$, the maximum penetration depth is inversely proportional to the density of the material to be irradiated. It is claimed that the penetration of the electrons into sludge matrix is only 2.5 $3 \mathrm{~mm}$ per $1 \mathrm{MeV}$ due to the presence of distorting compounds and differences in total solids content. However, due to the small differences in density, there are only minor changes in the MPD, indicating that the same beam energy can be used for different types of sludge.

- The electron beam facility needs to be designed with sufficient electron beam power and high electron beam utilisation capacity, as well as high accelerator electrical efficiency, to reduce unit operation cost and increase productivity along with possibly low electron energy for capital and operation cost reduction.

- The most important benefits of the electron beam sewage sludge treatment system are the possibility of removing various pollutants at the same time by both oxidation and reduction, low exploitation costs, the eco-friendly character of technology and the unit cost decrease along with the increase of the throughput and sludge biodegradability improvement. The most important disadvantages of the electron beam sewage sludge treatment are electron penetration limit and appropriate material distribution.

- Sludge sterilised with the e-beam can be used as soil fertiliser immediately after treatment, and no large land areas are needed for disposal for long periods.

- It is necessary to develop a normalised testing procedure and standardised requirements to enable cross-referencing between research facilities.

Funding This project has received funding from the European Union's Horizon 2020 Research and Innovation programme under Grant Agreement No. 730871.

Nomenclature $\mathrm{AD}$, anaerobic digestion; $\mathrm{ARP}$, advanced reduction process; $\mathrm{BCOD}$, biodegradable COD; BOD, biochemical oxygen demand; COD, chemical oxygen demand; CFU, colony forming unit; CSDA, continuous slowing down approximation range; DDIC, Daegu Dyeing Industrial Complex; DNA, deoxyribonucleic acid; DOC, dissolved organic carbon; DS, dry solids; EB, electron beam; EBRF, Electron Beam Research Facility; HM, heavy metal; HOC, halogenated organic compound; HRT, hydraulic retention time; ICOD, inert COD; IPCOD, inert particulate COD; IR, ionising radiation; ISCOD, inert soluble COD; MPD, maximum penetration depth; $\mathrm{PAH}$, polycyclic aromatic hydrocarbon; PCB, polychlorinated biphenyl; POP, persistent organic pollutant; PPCP, pharmaceutical and personal care product; RBCOD, readily biodegradable COD; RNA, ribonucleic acid; SBCOD, slowly/particulate biodegradable COD; SCOD, soluble COD; THP, thermal hydrolysis process; TS, total solids; WWTP, wastewater treatment plant

Open Access This article is licensed under a Creative Commons Attribution 4.0 International License, which permits use, sharing, adaptation, distribution and reproduction in any medium or format, as long as you give appropriate credit to the original author(s) and the source, provide a link to the Creative Commons licence, and indicate if changes were made. The images or other third party material in this article are included in the article's Creative Commons licence, unless indicated otherwise in a credit line to the material. If material is not included in the article's Creative Commons licence and your intended use is not permitted by statutory regulation or exceeds the permitted use, you will need to obtain permission directly from the copyright holder. To view a copy of this licence, visit http://creativecommons.org/licenses/by/4.0/.

\section{References}

Alcántara JM, Cruz AC, (1997). Bases for a sewage sludge treatment plant by irradiation in Mexico [WWW document]. URL https:// www.ipen.br/biblioteca/cd/inac/1997/ENAN/E03_018.PDF (accessed 22 Apr 2018).

Amoah ID, Adegoke AA, Stenström TA (2018) Soil-transmitted helminth infections associated with wastewater and sludge reuse: a review of current evidence. Tropical Med Int Health 23:692-703. https://doi.org/10.1111/tmi.13076

Andrady AL (2011) Microplastics in the marine environment. Mar Pollut Bull 62:1596-1605. https://doi.org/10.1016/j.marpolbul.2011.05. 030

Appels L, Baeyens J, Degrève J, Dewil R (2008) Principles and potential of the anaerobic digestion of waste-activated sludge. Prog Energy Combust Sci. https://doi.org/10.1016/j.pecs.2008.06.002

Asgari Lajayer B, Najafi N, Moghiseh E, Mosaferi M, Hadian J (2019) Effects of gamma irradiated and non-irradiated sewage sludge on growth characteristics, leaf chlorophyll index, and macronutrients concentrations in basil. J Soil Sci Plant Nutr 19:580-591. https:// doi.org/10.1007/s42729-019-00057-4

Astals S, Venegas C, Peces M, Jofre J, Lucena F, Mata-Alvarez J (2012) Balancing hygienization and anaerobic digestion of raw sewage sludge. Water Res 46:6218-6227. https://doi.org/10.1016/j.watres. 2012.07.035

Auerbach PS, 2011. Wilderness medicine, 6th ed. Elsevier.

Avery LM, Anchang KY, Tumwesige V, Strachan N, Goude PJ (2014) Potential for pathogen reduction in anaerobic digestion and biogas generation in Sub-Saharan Africa. Biomass Bioenergy 70:112-124. https://doi.org/10.1016/j.biombioe.2014.01.053

Bae BU, Jung ES, Kim YR, Shin HS (1999) Treatment of landfill leachate using activated sludge process and electron-beam radiation. Water Res 33:2669-2673. https://doi.org/10.1016/S0043-1354(98) 00488-6

Barber WPF (2016) Thermal hydrolysis for sewage treatment: a critical review. Water Res 104:53-71. https://doi.org/10.1016/j.watres. 2016.07.069 
Blewitt DA, (1989). Disinfection and oocysts. In Cryptosporidiosis. In: Proceedings of the first international workshop. pp. 107-111. https://doi.org/10.1128/microbe.8.242.1

Borrely SI, Cruz AC, Del Mastro NL, Sampa MHO, Somessari ES (1998) Radiation processing of sewage and sudge, A review. Prog Nucl Energy 33:3-21. https://doi.org/10.1017/CBO9781107415324.004

Buxton GV, Greenstock CL, Helman WP, Ross AB (1988) Critical review of rate constants for reactions of hydrated electrons, hydrogen atoms and hydroxyl radicals (OH/O-) in aqueous solution. J Phys Chem Ref Data 17:513-886. https://doi.org/10.1063/1.555805

Capizzi-Banas S, Schwartzbrod J (2001) Irradiation of Ascaris ova in sludge using an electron beam accelerator. Water Res 35:22562260. https://doi.org/10.1016/S0043-1354(00)00503-0

Capodaglio AG (2017) High-energy oxidation process: an efficient alternative for wastewater organic contaminants removal. Clean Techn Environ Policy 19:1995-2006. https://doi.org/10.1007/s10098-017$1410-5$

Carr SA, Liu J, Tesoro AG (2016) Transport and fate of microplastic particles in wastewater treatment plants. Water Res 91:174-182. https://doi.org/10.1016/j.watres.2016.01.002

Carrington E-G, (2001). Evaluation of sludge treatments for pathogen reduction, European Commission CO 5026/1.

Cavinato C, Fatone F, Bolzonella D, Pavan P (2010) Thermophilic anaerobic co-digestion of cattle manure with agro-wastes and energy crops: comparison of pilot and full scale experiences. Bioresour Technol 101:545-550. https://doi.org/10.1016/j.biortech.2009.08. 043

Changqing C, Min W (2012) Treatment of municipal sewage sludge by electron beam irradiation. Nucl Sci Tech 23:29-33

Chao AW, Chou W (2017) Reviews of accelerator science and technology. Rev Accel Sci Technol. https://doi.org/10.1142/10436

Chen T, Yan B (2012) Fixation and partitioning of heavy metals in slag after incineration of sewage sludge. Waste Manag 32:957-964. https://doi.org/10.1016/j.wasman.2011.12.003

Chmielewski AG, Sudlitz M (2019) 'Zero energy' electron beam technology for sludge hygienization. Nukleonika 64:55-63

Chmielewski AG, Zimek Z, Bryl-Sandelewska T, Kosmal W, Kalisz L, Kaźmierczuk M (1995) Disinfection of municipal sewage sludges in installation equipped with electron accelerator. Radiat Phys Chem 46:1071-1074. https://doi.org/10.1016/0969-806X(95)00323-P

Choi YY, Baek SR, Kim JI, Choi JW, Hur J, Lee TU, Park CJ, Lee BJ (2017) Characteristics and biodegradability of wastewater organic matter in municipal wastewater treatment plants collecting domestic wastewater and industrial discharge. Water 9. https://doi.org/10. 3390/w9060409

Cleland MR, (2006). Industrial applications of electron accelerators, in: CAS 2005 - CERN Accelerator School: Small Accelerators, Proceedings. pp. 383-416.

Coburn B, Grassl GA, Finlay BB (2007) Salmonella, the host and disease: a brief review. Immunol Cell Biol. https://doi.org/10.1038/sj. icb. 7100007

Cooper WJ, Gehringer P, Pikaev AK, Kurucz CN, Mincher BJ (2004) Radiation processes. In: Parsons S (ed) Advanced oxidation processes for water and wastewater treatment. IWA Publishing, London, pp 209-246

Cordella M, Kaps R (2018) Designing sustainable technologies, products and policies. Luxembourg. https://doi.org/10.1007/978-3-31966981-6_52

Cross JD, Jayaram S (1998) Removal of volatile organic compounds in water using low-energy electron beam. IEEE Trans Dielectr Electr Insul 5:7-9

da Silva Aquino KA, (2012). Sterilization by gamma irradiation, gamma radiation. https://doi.org/10.5772/34901

DEFRA, 2012. Waste water treatment in the United Kingdom [WWW Document]. Defra. www.defra.gov.uk/environment/quality/water/ sewage/sewage-treatment. Accessed 14 June 2018
Demirci A, Ngadi MO (2012) Microbial decontamination in the food industry. Novel Methods Appl. https://doi.org/10.1533/ 9780857095756

Duarte CL, Sampa MHO, Rela PR, Oikawa H, Silveira CG, Azevedo AL (2002) Advanced oxidation process by electron-beam-irradiationinduced decomposition of pollutants in industrial effluents. Radiat Phys Chem 63:647-651. https://doi.org/10.1016/S0969-806X(01) 00560-6

Duarte CL, Geraldo LL, Junior ODAP, Borrely SI, Sato IM, Sampa MHDO, (2004). Treatment of effluents from petroleum production by electron beam irradiation. In: Radiation Physics and Chemistry. pp. 445-449. https://doi.org/10.1016/j.radphyschem.2004.03.021

Dwyer J, Starrenburg D, Tait S, Barr K, Batstone DJ, Lant P (2008) Decreasing activated sludge thermal hydrolysis temperature reduces product colour, without decreasing degradability. Water Res 42: 4699-4709. https://doi.org/10.1016/j.watres.2008.08.019

Dyke PH, Foan C, Fiedler H (2003) PCB and PAH releases from power stations and waste incineration processes in the UK. Chemosphere 50:469-480. https://doi.org/10.1016/S0045-6535(02)00627-6

Eckert EM, Di Cesare A, Kettner MT, Arias-Andres M, Fontaneto D, Grossart HP, Corno G (2018) Microplastics increase impact of treated wastewater on freshwater microbial community. Environ Pollut 234:495-502. https://doi.org/10.1016/j.envpol.2017.11.070

Engohang-Ndong J, Uribe RM, Gregory R, Gangoda M, Nickelsen MG, Loar P (2015) Effect of electron beam irradiation on bacterial and Ascaris ova loads and volatile organic compounds in municipal sewage sludge. Radiat Phys Chem 112:6-12. https://doi.org/10. 1016/j.radphyschem.2015.02.013

Environment Agency, 2003. The microbiology of sewage sludge (2003). Part 1: an overview of the treatment and use in agriculture of sewage sludge in relation to its impact on the environment and public health. Methods for the Examination of Waters and Associated Materials.

Farooq S, Kurucz CN, Waite TD, Cooper WJ, Mane SR, Greenfield JH (1992) Treatment of wastewater with high energy electron beam irradiation. Wat SciTech. 26:1265-1274

Fernandes F, Lopes DD, Andreoli CV, da Silva SMCP (2007) Biological wastewater treatment. In: assessment of sludge treatment and disposal alternatives, sludge treatment and disposal, 6th edn. IWA Publishing, London. https://doi.org/10.1016/B978-1-85617-705-4. 00021-6

Freita-Silva O, de Oliveira PS, Freire Júnior M (2015) Potential of electron beams to control mycotoxigenic fungi in food. Food Eng Rev 7: 160-170. https://doi.org/10.1007/s12393-014-9093-8

Fu SF, Ding JN, Zhang Y, Li YF, Zhu R, Yuan XZ, Zou H (2018) Exposure to polystyrene nanoplastic leads to inhibition of anaerobic digestion system. Sci Total Environ 625:64-70. https://doi.org/10. 1016/j.scitotenv.2017.12.158

Gann V, Den Hartog H, Sugonyako A, Vainshtein D (2004) The energy deposition profile of 0.1-3.0 MeV electrons in $\mathrm{NaCl}$, in. Proceedings of EPAC Lucerne, Switzerland, pp 2756-2758

Garcia MM, Brooks BW, Stewart RB, Dion W, Trudel JR, Ouwerkerk T (1987) Evaluation of gamma radiation levels for reducing pathogenic bacteria and fungi in animal sewage and laboratory effluents. Can J Vet Res 51:285-289

Gardner M, Jones V, Comber S, Scrimshaw MD, Coello-Garcia T, Cartmell E, Lester J, Ellor B (2013) Performance of UK wastewater treatment works with respect to trace contaminants. Sci Total Environ 456-457:359-369. https://doi.org/10.1016/j.scitotenv. 2013.03.088

Gautam RK, Nagar V, Shashidhar R (2015) Effect of radiation processing in elimination of Klebsiella pneumoniae from food. Radiat Phys Chem 115:107-111. https://doi.org/10.1016/j.radphyschem.2015. 06.016

Gerber M, Schneider N (2015) Density of biogas digestate depending on temperature and composition. Bioresour Technol 192:172-176. https://doi.org/10.1016/j.biortech.2015.05.061 
Getof N (1995) Radiation-induced degradation of water pollutants-state of the art. Radiat Phys Chem 47:581-593. https://doi.org/10.1016/ 0969-806X(95)00059-7

Gholami M, Nassehinia HR, Jonidi-Jafari A, Nasseri S, Esrafili A, 2014. Comparison of benzene \& toluene removal from synthetic polluted air with use of nano photocatalytic $\mathrm{TiO} / \mathrm{ZNO}$ process. J Environ Heal Sci Eng. 12. https://doi.org/10.1186/2052-336X-12-45

Gies EA, LeNoble JL, Noël M, Etemadifar A, Bishay F, Hall ER, Ross PS (2018) Retention of microplastics in a major secondary wastewater treatment plant in Vancouver, Canada. Mar Pollut Bull 133: 553-561. https://doi.org/10.1016/j.marpolbul.2018.06.006

GIPA, iia, (2017). A comparison of gamma, e-beam, X-ray and ethylene oxide technologies for the industrial sterilization of medical devices and healthcare products

Greenpeace, (2019). Upstream: microplastics in UK rivers.

Hamm RW, Hamm ME (2012) Industrial accelerators and their applications. World Sci Publ Co. https://doi.org/10.1142/7745

Han B, Ko J, Kim J, Kim Y, Chung W, Makarov IE, Ponomarev AV, Pikaev AK (2002) Combined electron-beam and biological treatment of dyeing complex wastewater. Pilot plant experiments. Radiat Phys Chem 64:53-59

Han B, Kyu Kim J, Kim Y, Seung Choi J, Young Jeong K (2012) Operation of industrial-scale electron beam wastewater treatment plant. Radiat Phys Chem 81:1475-1478. https://doi.org/10.1016/j. radphyschem.2012.01.030

He S, Sun W, Wang J, Chen L, Zhang Y, Yu J (2016) Enhancement of biodegradability of real textile and dyeing wastewater by electron beam irradiation. Radiat Phys Chem 124:203-207. https://doi.org/ 10.1016/j.radphyschem.2015.11.033

Horton AA, Walton A, Spurgeon DJ, Lahive E, Svendsen C (2017) Microplastics in freshwater and terrestrial environments: evaluating the current understanding to identify the knowledge gaps and future research priorities. Sci Total Environ. https://doi.org/10.1016/j. scitotenv.2017.01.190

Hossain K, Maruthi YA, Das NL, Rawat KP, Sarma KSS (2018) Irradiation of wastewater with electron beam is a key to sustainable smart/green cities: a review. Appl Water Sci 8:6. https://doi.org/10. 1007/s13201-018-0645-6

International Atomic Energy Agency (2008) Radiation treatment of polluted water and wastewater. In: Industrial Applications in Chemistry Section, IAEA. IAEA, Vienna, p 222

International Atomic Energy Agency, (2005). Radiation treatment of gaseous and liquid effluents for contaminant removal, in: Technical Meeting Held in Sofia.

Johnke B, 1996. Emissions from waste incineration. In: Good practice guidance and uncertainty management in national greenhouse gas inventories. Intergovernmental Panel on Climate Change, Montreal, pp. $455-468$.

Kaplan JE, Masur H, Holmes KK (2002) Guidelines for preventing opportunistic infections among HIV-infected persons-2002. Recommendations of the U.S. Public Health Service and the Infectious Diseases Society of America. MMWR Recomm Rep 51:1-52. https://doi.org/10.7326/0003-4819-137-5_part_2200209031-00002

Khan JA, Shah NS, Khan HM (2015) Decomposition of atrazine by ionizing radiation: kinetics, degradation pathways and influence of radical scavengers. Sep Purif Technol 156:140-147. https://doi.org/ 10.1016/j.seppur.2015.09.064

Kim SM, Han B, Kim JK, Kim KY, Choi JS, Ahn JS, Salimov RA, Kim $\mathrm{KN}$, (2006). Application of high power electron accelerator in wastewater treatment, in: RUPAC-2006. Novosibirsk, p. 42.

Kim TH, Lee JK, Lee MJ (2007) Biodegradability enhancement of textile wastewater by electron beam irradiation. Radiat Phys Chem 76: 1037-1041. https://doi.org/10.1016/j.radphyschem.2006.10.001

Kim Y, Han B, Kim JK, Ben Yaacov N, Jeong KY, 2009. Design of electron beam sludge hygienization plant. In: International topical meeting on nuclear research applications and utilization of accelerators.

Kim GR, Ramakrishnan SR, Kwon JH (2018) Radiosensitivity of microorganisms in Saengshik products and irradiation effects on the sensorial properties. Radiat Phys Chem 152:100-106. https://doi.org/ 10.1016/j.radphyschem.2018.08.006

Krumeich, B.F., (2018). Properties of electrons, their interactions with matter [WWW document]. URL www.microscopy.ethz.ch (accessed 18 Aug 2018).

Kurucz CN, Waite TD, Cooper WJ, Nickelsen MJ (1991). Advances in nuclear science and technology, in: Proceedings of the 45th Industrial Waste Conference May 8,9,10, 1990. https://doi.org/10. 1007/978-1-4615-3392-4

Kurucz CN, Waite TD, Cooper WJ (1995) The Miami electron beam research facility: a large scale wastewater treatment application. Radiat Phys Chem 45:299-308. https://doi.org/10.1016/0969806X(94)00075-1

Labbe RG, Juneja VK, (2017). Clostridium perfringens. In: Foodborne diseases: third edition. Elsevier Inc., pp. 235-242. https://doi.org/10. 1016/B978-0-12-385007-2.00010-3

Lasee S, Mauricio J, Thompson WA, Karnjanapiboonwong A, Kasumba J, Subbiah S, Morse AN, Anderson TA (2017) Microplastics in a freshwater environment receiving treated wastewater effluent. Integr Environ Assess Manag 13:528-532. https://doi.org/10.1002/ieam. 1915

Laurent J, Casellas M, Carrere H, Dagot C (2011) Effects of thermal hydrolysis on activated sludge slubilization, surface properties and heavy metals biosorption. Chem Eng J 166:841-849

Le Caër S (2011) Water radiolysis: influence of oxide surfaces on $\mathrm{H} 2$ production under ionizing radiation. Water 3:235-253. https://doi. org/10.3390/w3010235

Lemée L, Collard M, Vel Leitner NK, Teychené B (2017) Changes in wastewater sludge characteristics submitted to thermal drying, ebeam irradiation or anaerobic digestion. Waste Biomass Valorization 8:1771-1780. https://doi.org/10.1007/s12649-0179946-5

Lenaghan S, (2008). Molecular responses of Giardia lamblia to gammairradiation. Auburn University.

Levantesi C, Beimfohr C, Blanch AR, Carducci A, Gianico A, Lucena F, Tomei MC, Mininni G (2015) Hygienization performances of innovative sludge treatment solutions to assure safe land spreading. Environ Sci Pollut Res 22:7237-7247. https://doi.org/10.1007/ s11356-014-3572-6

Liao Yinguang Chen J (2018) Removal of intll and associated antibiotics resistant genes in water, sewage sludge and livestock manure treatments. Rev Environ Sci Bio/Technol. https://doi.org/10.1007/ s11157-018-9469-y

Lim SJ, Kim TH, Kim JY, Shin IH, Kwak HS (2016) Enhanced treatment of swine wastewater by electron beam irradiation and ion-exchange biological reactor. Sep Purif Technol 157:72-79. https://doi.org/10. 1016/j.seppur.2015.11.023

Lin WY, Ng WC, Wong BSE, Teo SLM, do Sivananthan G, Baeg GH, Ok YS, Wang CH (2018) Evaluation of sewage sludge incineration ash as a potential land reclamation material. J Hazard Mater 357:6372. https://doi.org/10.1016/j.jhazmat.2018.05.047

Liu Z, Qian G, Sun Y, Xu R, Zhou J, Xu Y (2010) Speciation evolutions of heavy metals during the sewage sludge incineration in a laboratory scale incinerator. Energy Fuel 24:2470-2478. https://doi.org/ 10.1021/ef901060u

Lock EH, Petrovykh DY, Mack P, Carney T, White RG, Walton SG, Fernsler RF (2010) Surface composition, chemistry, and structure of polystyrene modified by electron-beam-generated plasma. Langmuir 26:8857-8868. https://doi.org/10.1021/la9046337

Mahon AM, O'Connel B, Healy MG, O'Connor I, Officer R, Nash R, Morrison L, 2016. Microplastics in sewage sludge: effects of 
treatment. Environ Sci Technol 9. https://doi.org/10.1021/acs.est. $6 \mathrm{~b} 04048$

Malmborg J, Magnér J (2015) Pharmaceutical residues in sewage sludge: effect of sanitization and anaerobic digestion. J Environ Manag 153: 1-10. https://doi.org/10.1016/j.jenvman.2015.01.041

Maruthi YA, Das NL, Hossain K, Sarma KSS, Rawat KP, Sabharwal S (2011a) Application of electron beam technology in improving sewage water quality : an advance technique. Afr J Environ Sci Technol 5:545-552. https://doi.org/10.5897/AJEST11.072

Maruthi YA, Khrapov SS, Hossain K, Rawat KP (2011b) Advance oxidation of sewage water, reclamation and hygienization by radiation technology: a novel approach. J Waste Water Treat Anal 02:1. https://doi.org/10.4172/2157-7587.1000108

Maruthi YA, Das NL, Hossain K, Rawat KP, Sarma KS, Sabharwal S (2013) Appliance of electron beam technology for disinfection of sewage water to minimize public health risks. Eur J Sustain Dev 2: 31-42. https://doi.org/10.14207/ejsd.2013.v2n2p31

McClane BA, (2014). Clostridium perfringens. In: Encyclopedia of toxicology: third edition. Elsevier, pp. 987-988. https://doi.org/10. 1016/B978-0-12-386454-3.00081-6

Mckeown J (1996) Electron sterilization of sewage sludge: a real case comparison with other process. Radiat Phys Chem 47:469-473. https://doi.org/10.1016/0969-806X(95)00130-P

Mills N, (2015). Unlocking the full energy potential of sewage sludge. Doctoral thesis. p. 117

Mladenović MR, Dakić DV, Nemoda S, Paprika MJ, Komatina MS, Repić BS, Erić AM (2016) The combustion of biomass - the impact of its types and combustion technologies on the emission of nitrogen oxide. Hem Ind 70:287-298. https://doi.org/10.2298/ HEMIND150409033M

Mocé-Llivina L, Muniesa M, Pimenta-Vale H, Lucena F, Jofre J (2003) Survival of bacterial indicator species and bacteriophages after thermal treatment of sludge and sewage. Appl Environ Microbiol 69: 1452-1456. https://doi.org/10.1128/AEM.69.3.1452-1456.2003

Moraes MCF, Romanelli MF, Sena HC, Pasqualini Da Silva G, Sampa O, Borrely SI (2004) Whole acute toxicity removal from industrial and domestic effluents treated by electron beam radiation: emphasis on anionic surfactants. Radiat Phys Chem 71:461-463. https://doi.org/ 10.1016/j.radphyschem.2004.03.022

Moreira RG, Puerta-Gomez AF, Kim J, Castell-Perez ME (2012) Factors affecting radiation D-values (D10) of an Escherichia coli cocktail and Salmonella typhimurium LT2 inoculated in fresh produce. J Food Sci 77:104-111. https://doi.org/10.1111/j.1750-3841.2011. 02603.x

Mumy KL, (2014). Salmonella. In: Encyclopedia of toxicology: third edition. Elsevier, pp. 211-212. https://doi.org/10.1016/B978-0-12386454-3.00537-6

Murphy F, Ewins C, Carbonnier F, Quinn B (2016) Wastewater treatment works (WwTW) as a source of microplastics in the aquatic environment. Environ Sci Technol 50:5800-5808. https://doi.org/10.1021/ acs.est.5b05416

Myszograj S, Płuciennik-Koropczuk E, Jakubaszek A (2017) Cod fractions - methods of measurement and use in wastewater treatment technology. Civ Environ Eng Reports 24:195-206. https://doi.org/ 10.1515/ceer-2017-0014

Nasseri S, Mahvi AH, Seyedsalehi M, Yaghmaeian K, Nabizadeh R, Alimohammadi M, Safari GH (2017) Degradation kinetics of tetracycline in aqueous solutions using peroxydisulfate activated by ultrasound irradiation: effect of radical scavenger and water matrix. J Mol Liq 241:704-714. https://doi.org/10.1016/j.molliq.2017.05. 137

National Institute of Standards and Technology 2018. ESTAR : stopping power and range tables for electrons [WWW document]. URL https://physics.nist.gov/PhysRefData/Star/Text/ESTAR.html (accessed 12 Sep 2018).
Nickelsen MG, Cooper WJ, Lin K, Kurucz CN, Waite TD (1994) High energy electron beam generation of oxidants for the treatment of benzene and toluene in the presence of radical scavengers. Pergamon Wat Res 28:1227-1237

Ofwat, (2016). Ofwat: bioresources market discussions continue $-84 \%$ of sludge treated by AD [WWW document]. URL https://www. waterbriefing.org/home/bioresources/item/13166-ofwatbioresources-market-discussions-continue---84-of-sludge-treatedby-ad (accessed 5 July 2018).

Orhon D, Cokgor EU, (1997). COD fractionation in wastewater characterization - the state of the art. J Chem Technol Biotechnol. 4660. https://doi.org/10.1002/(SICI)1097-4660(199703)68

Park W, Hwang MH, Kim TH, Lee MJ, Kim IS (2009) Enhancement in characteristics of sewage sludge and anaerobic treatability by electron beam pre-treatment. Radiat Phys Chem 78:124-129. https:// doi.org/10.1016/j.radphyschem.2008.09.010

Paul J, Rawat KP, Sarma KSS, Sabharwal S (2011) Decoloration and degradation of Reactive Red-120 dye by electron beam irradiation in aqueous solution. Appl Radiat Isot 69:982-987. https://doi.org/ 10.1016/j.apradiso.2011.03.009

Phan HV, Wickham R, Xie S, McDonald JA, Khan SJ, Ngo HH, Guo W, Nghiem LD (2018) The fate of trace organic contaminants during anaerobic digestion of primary sludge: a pilot scale study. Bioresour Technol 256:384-390. https://doi.org/10.1016/j.biortech.2018.02. 040

Pickworth B, Cranshaw I, Abraham K, Coleman P, Walley P, Solheim OE (2012) Large scale reality of sewage sludge pasteurisation and thermal hydrolysis. Proc Water Environ Fed 2005:2794-2802. https://doi.org/10.2175/193864705783865361

Pikaev AK, Kartasheva LI, Zhestkova YP, Yurik TK, Chulkov VN, Didenko OA, Kyung Kim D, Kim Y, Han B, I CI (1997) Removal of heavy metals from water by electron-beam treatment in the presence of an hydroxyl radical scavenger. Mendeleev Commun 7:52-53. https://doi.org/10.1070/ MC1997v007n02ABEH000716

Pillai SD, Reimers RS, (2013). Stabilization and disinfection of wastes using high energy E-beam and chemical oxidants.

Prata JC (2018) Microplastics in wastewater: state of the knowledge on sources, fate and solutions. Mar Pollut Bull 129:262-265. https:// doi.org/10.1016/j.marpolbul.2018.02.046

Praveen C, Jesudhasan PR, Reimers RS, Pillai SD (2013) Electron beam inactivation of selected microbial pathogens and indicator organisms in aerobically and anaerobically digested sewage sludge. Bioresour Technol 144:652-657. https://doi.org/10.1016/j. biortech.2013.07.034

Pribil W, Gehringer P, Eschweiler H, Cabaj A, Haider T, Sommer R (2007) Assessment of Bacillus subtilis spores as a possible bioindicator for evaluation of the microbicidal efficacy of radiation processing of water. Water Environ Res 79:720-724. https://doi.org/ 10.2175/106143007X175889

Priyadarshini J, Roy PK, Mazumdar A (2014) Qualitative and quantitative assessment of sewage sludge by gamma irradiation with pasteurization as a tool for hygienization. J Inst Eng Ser A 95:49-54. https://doi.org/10.1007/s40030-014-0073-z

Rajkowski KT (2016) Radiation D 10-values on thawed and frozen catfish and tilapia for finfish isolates of Listeria monocytogenes. J Food Prot 71:2278-2282. https://doi.org/10.4315/0362-028x-71.11.2278

Ram S, Vajpayee P, Shanker R (2007) Prevalence of multi-antimicrobialagent resistant shiga toxin and enterotoxin producing Escherichia coli in surface waters of river Ganga. Environ Sci Technol 41: 7383-7388. https://doi.org/10.1021/es0712266

Rathod PH, Patel JC, Shah MR, Jhala AJ (2009) Recycling gamma irradiated sewage sludge as fertilizer: a case study using onion (Alium cepa). Appl Soil Ecol 41:223-233. https://doi.org/10.1016/j.apsoil. 2008.11.001 
Rawat KP, Sarma KSS (2013) Enhanced biodegradation of wastewater with electron beam pretreatment. Appl Radiat Isot 74:6-8. https:// doi.org/10.1016/j.apradiso.2012.12.013

Royal Commission on Sewage Disposal, (1915). Final report of the commissioners appointed to inquire and report what methods of treating and disposing of sewage (including any liquid from any factory or manufacturing process) may properly be adopted: general summary of conclusions and recommendation.

Sabharwal S, 2013. Electron beam irradiation applications. Proc. 25th North Am Part Accel Conf. 745-748.

Sassi HP, Ikner LA, Abd-Elmaksoud S, Gerba CP, Pepper IL (2018) Comparative survival of viruses during thermophilic and mesophilic anaerobic digestion. Sci Total Environ 615:15-19. https://doi.org/ 10.1016/j.scitotenv.2017.09.205

Schmelling D, Poster D, Chaychian M, Neta P, Mclaughlin W, Silverman J, Al-Sheikhly M, 1998. Application of ionising radiation to the remediation of materials contaminated with heavy metals and polychlorinated biphenyls. Radiat Phys Chem.

Shin K, Kang H (2003) Electron beam pretreatment of sewage sludge before anaerobic digestion. Appl Biochem Biotechnol 109:227-239

Shin H-S, Kim Y-R, Han B, Makarov IE, Ponomarev AV, Pikaev AK (2002) Application of electron beam to treatment of wastewater from papermill. Radiat Phys Chem 65:539-547. https://doi.org/10. 1016/S0969-806X(02)00348-1

Skowron K, Olszewska H, Paluszak Z, Zimek Z, Kałuska I, Skowron KJ (2013) Radiation hygienization of cattle and swine slurry with high energy electron beam. Radiat Phys Chem 87:88-96. https://doi.org/ 10.1016/j.radphyschem.2013.02.008

Skowron K, Olszewska H, Paluszak Z, Zimek Z, Kałuska I, Skowron KJ, (2018). Radiation hygienization of cattle and swine slurry with high energy electron beam. In: Workshop of the emerging trends in the sludge treatment. https://doi.org/10.1016/j.radphyschem.2013.02. 008

Somers C, 2004. D-10 value and elimination of food-borne pathogens. In: CIRMS, Gaithersburg.

Sommers CH, Boyd G (2006) Radiation sensitivity and postirradiation growth of foodborne pathogens on a ready-to-eat frankfurter on a roll product in the presence of modified atmosphere and antimicrobials. J Food Prot 69:2436-2440. https://doi.org/10.4315/0362028X-69.10.2436

Son Y-S (2017) Decomposition of VOCs and odorous compounds by radiolysis: a critical review. Chem Eng J 316:609-622. https://doi. org/10.1016/j.cej.2017.01.063

Sperling M (2005) Biological wastewater treatment in warm climate regions. In: IWA Publishing, 1st edn. IWA Publishing, London. https://doi.org/10.5860/CHOICE.45-2633

Stadlbauer JM, Venkateswaran K, Walker DC (1997) Muonium reactions with chloroacetic acid in water: contrasts with $\mathrm{H}$ atoms and hydrated electrons. Radiat Phys Chem 50:259-262. https://doi.org/10.1016/ S0969-806X(97)00033-9

Strydom W, Parker W, Olivares M, (2006). Chapter 8 electron beams: physical and clinical aspects. In: Podgorsak EB. (Ed.), Radiation oncology physics: a handbook for teachers and students. pp. 1-46.

Sun Y, Chmielewski AG, (2017). Applications of ionising radiation in material processing Vol. 1. Institute of Nuclear Chemistry and Technology, Warsaw.

Świerczek L, Cieślik BM, Konieczka P (2018) The potential of raw sewage sludge in construction industry - a review. J Clean Prod 200:342-356. https://doi.org/10.1016/j.jclepro.2018.07.188

Taboada-Santos A, Braz GHR, Fernandez-Gonzalez N, Carballa M, Lema JM (2019) Thermal hydrolysis of sewage sludge partially removes organic micropollutants but does not enhance their anaerobic biotransformation. Sci Total Environ 690:534-542. https://doi. org/10.1016/j.scitotenv.2019.06.492
Takács E, Wojnárovits L, Pálfi T (2007) Azo dye degradation by highenergy irradiation: kinetics and mechanism of destruction. Nukleonika 52:69-75

Takeshita H, Naramoto H (1992) (Jaeri) International conference on evolution in beam application: November $5 \sim 8,1991$ Takasaki, Japan. J Nucl Sci Technol 29:408-411. https://doi.org/10.1080/18811248. 1992.9731542

Talvitie J, Mikola A, Koistinen A, Setälä O (2017) Solutions to microplastic pollution - removal of microplastics from wastewater effluent with advanced wastewater treatment technologies. Water Res 123:401-407. https://doi.org/10.1016/j.watres.2017.07.005

Tell J, Caldwell DJ, Häner A, Hellstern J, Hoeger B, Journel R, Mastrocco F, Ryan JJ, Snape J, Straub JO, Vestel J (2019) Science-based targets for antibiotics in receiving waters from pharmaceutical manufacturing operations. Integr Environ Assess Manag 15:312-319. https://doi.org/10.1002/ieam.4141

Tobien T, Cooper WJ, Nickelsen MG, Pernas E, O'Shea KE, Asmus K-D (2000) Odor control in wastewater treatment: the removal of thioanisole from a water model case study by pulse radiolysis and electron beam treatment. Environ Sci Technol 34:1286-1291. https://doi.org/10.1021/es990692v

Trump JG, Merrill EW, Wright K a (1984) Disinfection of sewage wastewater and sludge by electron treatment. Radiat Phys Chem 24:55-66

U.S. Environmental Protection Agency, (2011). Code of Federal Regulations, 40 CFR Part 133. Secondary Treatment Regulation.

US EPA (2003) Environmental regulations and technology control of pathogens and vector attraction in sewage sludge control of pathogens and vector attraction. Environ Prot 47:498-504. https://doi.org/ 10.1016/S0015-1882(99)80035-4

van Gerwen SJC, Rombouts FM, van't Riet K, Zwietering MH (2016) A data analysis of the irradiation parameter D 10 for bacteria and spores under various conditions. J Food Prot 62:1024-1032. https://doi.org/10.4315/0362-028x-62.9.1024

Varel VH, Wells JE, Shelver WL, Rice CP, Armstrong DL, Parker DB (2012) Effect of anaerobic digestion temperature on odour, coliforms and chlortetracycline in swine manure or monensin in cattle manure. J Appl Microbiol 112:705-715. https://doi.org/10.1111/j. 1365-2672.2012.05250.x

Vieira Da Rocha MC, Eboly Bar M, Cristina M, Braga B, (2016). Quantification of viable helminth eggs in samples of sewage sludge. https://doi.org/10.1016/j.watres.2016.07.039

Waite TD, Kurucz CN, Cooper WJ, Brown D, Gables C, (1985). Full scale electron beam systems for treatment of water, wastewater and medical waste. In: IAEA-SM-350/54. pp. 187-201.

Wang J, Chu L (2016) Irradiation treatment of pharmaceutical and personal care products (PPCPs) in water and wastewater: an overview. Radiat Phys Chem. https://doi.org/10.1016/j.radphyschem.2016.03. 012

Wang X, Andrade N, Shekarchi J, Fischer SJ, Torrents A, Ramirez M (2018) Full scale study of class A biosolids produced by thermal hydrolysis pretreatment and anaerobic digestion. Waste Manag 78: 43-50. https://doi.org/10.1016/j.wasman.2018.05.026

Wang M, Li R, Zhao Q, (2019). Distribution and removal of antibiotic resistance genes during anaerobic sludge digestion with alkaline, thermal hydrolysis and ultrasonic pretreatments. Front Environ Sci Eng 13. https://doi.org/10.1007/s11783-019-1127-2

Wei W, Huang QS, Sun J, Dai X, Ni BJ (2019a) Revealing the mechanisms of polyethylene microplastics affecting anaerobic digestion of waste activated sludge. Environ Sci Technol 53:9604-9613. https:// doi.org/10.1021/acs.est.9b02971

Wei W, Huang QS, Sun J, Wang JY, Wu SL, Ni BJ (2019b) Polyvinyl chloride microplastics affect methane production from the anaerobic digestion of waste activated sludge through leaching toxic bisphenol-A. Environ Sci Technol 53:2509-2517. https://doi.org/ 10.1021/acs.est.8b07069 
WHO, (2005). Guidelines for the control of shigellosis, including epidemics due to Shigella dysenteriae type 1.

WHO, (2018). E. coli [WWW Document]. URL https://www.who.int/ news-room/fact-sheets/detail/e-coli (accessed 3 July 2020).

William JC, Nickelsen MG, Tobien T, Mincher BJ, 2001. Radiationinduced oxidation. In: Chang, O.H. (Ed.), Hazardous and radioactive waste treatment technologies handbook. CRC, p. 13. https://doi. org/10.1201/9781420036459

Wojnárovits L, Takács E (2008) Irradiation treatment of azo dye containing wastewater: an overview. Radiat Phys Chem. https://doi.org/10. 1016/j.radphyschem.2007.05.003

Wojnarovits L, Palfi T, Takacs E, Emmi SS (2005) Reactivity differences of hydroxyl radicals and hydrated electrons in destructing azo dyes. Radiat Phys Chem 74:239-246. https://doi.org/10.1016/j. radphyschem.2005.04.019

Xue Y, Liu H, Chen S, Dichtl N, Dai X, Li N (2015) Effects of thermal hydrolysis on organic matter solubilization and anaerobic digestion of high solid sludge. Chem Eng J 264:174-180. https://doi.org/10. 1016/j.cej.2014.11.005

Yang S, McDonald J, Hai FI, Price WE, Khan SJ, Nghiem LD (2017) Effects of thermal pre-treatment and recuperative thickening on the fate of trace organic contaminants during anaerobic digestion of sewage sludge. Int Biodeterior Biodegrad 124:146-154. https:// doi.org/10.1016/j.ibiod.2017.06.002

Yao, S., Dou, D., Fu, H., Liu, S., Wang, S., Sun, X., (2005). Innovation technique of radiation for the treatment of 4-chlorphenol as a model of POPs in waste water. Nuclear Instrum Methods Physics Res B: Beam Interactions with Materials and Atoms. Pm, pp. 266-271. https://doi.org/10.1016/j.nimb.2005.03.249

Zamula E, (1991). A new challenge for former polio patients. FDA Consum. 25.
Zhang Z, Chen Y, (2020). Effects of microplastics on wastewater and sewage sludge treatment and their removal: a review. Chem Eng J 385. https://doi.org/10.1016/j.cej.2019.122955

Zhao Q, Liu Y (2019) Is anaerobic digestion a reliable barrier for deactivation of pathogens in biosludge? Sci Total Environ. https://doi.org/ 10.1016/j.scitotenv.2019.03.063

Zheng Z, Kazumi J, Waite TD, (2001). Irradiation effects on suspended solids in sludge. Radiat Physics Chem. pp. 709-710. https://doi.org/ 10.1016/S0969-806X(01)00382-6

Zhorin VA, Kiselev MR, Roldughin VI (2018) Thermal processes in aluminum blends with some alcohols after high-pressure plastic deformation. Colloid J 80:382-388. https://doi.org/10.1134/ S1061933X18040154

Zhou J, Xu W, Wong JWC, Yong X, Yan B, Zhang X, Jia H, 2015. Ultrasonic and thermal pretreatments on anaerobic digestion of petrochemical sludge: dewaterability and degradation of PAHs. PLoS One 10. https://doi.org/10.1371/journal.pone.0136162

Ziajahromi S, Neale PA, Rintoul L, Leusch FDL (2017) Wastewater treatment plants as a pathway for microplastics: development of a new approach to sample wastewater-based microplastics. Water Res 112:93-99. https://doi.org/10.1016/j.watres.2017.01.042

Zimek Z (1998) Electron accelerators for environmental protection. World Sci Pub Co Pte Lt. https://doi.org/10.1142/ S1793626811000501

Zona R, Solar S, Getoff N, Sehested K, Holcman J (2008) Reactivity of H atoms and hydrated electrons with chlorobenzoic acids. Radiat Phys Chem 77:162-168. https://doi.org/10.1016/j.radphyschem.2007.05. 001

Publisher's note Springer Nature remains neutral with regard to jurisdictional claims in published maps and institutional affiliations. 